\title{
The Use of Rotating Cylinder Electrode to Study the Effect of 1,3-Dihydroxypropane on the Production of Copper Powder
}

\author{
H. M. A. Soliman ${ }^{*, a}$ and H. H. Abdel-Rahman ${ }^{b}$ \\ ${ }^{a}$ Institute of New Materials and Advanced Technologies, Mubarak City for Scientific Research and Technology \\ Applications, New Borg El-Arab City, P.O. Box 21934 Alexandria, Egypt \\ ${ }^{b}$ Chemistry Department, Faculty of Science, Alexandria University, P.O. Box 426, Ibrahimia 21321, Alexandria, Egypt
}

O efeito de diferentes concentrações de 1,3-diidroxipropano (DHP) na eletrodeposição de cobre a partir de soluções de sulfato de cobre acidificado, tem sido estudado em diferentes temperaturas e velocidades de rotação. A eletrodeposição de cobre foi obtida sobre um eletrodo de cilindro rotatório (RCE) de cobre puro. A porcentagem de inibição, P, no cobre eletrodepositado foi $0,00-92,91 \%$, dependendo das variáveis experimentais. P depende da temperatura e fração molar de DHP, enquanto a rotação não mostrou nenhuma influência. Os valores da energia de ativação do processo de eletrodeposição, $\mathrm{E}_{\mathrm{a}}$, encontrados, foram menores do que $28 \mathrm{~kJ} \mathrm{~mol}^{-1}$, indicando que o processo é controlado por difusão. As correlações da transferência de massa global, nas presentes condições, têm sido obtidas usando-se o método de análise dimensional. Os dados foram válidos para $80<\mathrm{Sh}$ $(\mathrm{Sh}=$ número de Sherwood $)<3970,290<\mathrm{Sc}(\mathrm{Sc}=$ número de Schmidt $)<59284$ and $271<\operatorname{Re}(\operatorname{Re}$ $=$ número de Reynolds) $<52705$ e os resultados concordaram com os estudos prévios de transferência de massa para cilindros rotatórios em regimes de fluxo turbulento. Determinação experimental da velocidade crítica da solução foi obtida para branco e solução de DHP a 20\% (v/v) em 298 K. O efeito do tempo, quantidade de DHP, temperatura e velocidade de rotação nas mudanças morfológicas do cobre em pó eletrodepositado, bem como a composição do depósito e tamanho de partícula, têm sido estudados. Vários tamanhos de partículas, no intervalo de 60,5 a 203,4 nm foram obtidos e caracterizados por EDS e XRD, tendo-se encontrado que as partículas eram de cobre puro com pequena quantidade de oxigênio. Diferentes topografias provaram que a razão da eletrodeposição de cobre aumenta com o aumento do tempo, temperatura e velocidade de rotação. Além disso, foi provado que a razão da eletrodeposição decresce pela adição de DHP à solução. Entretanto, os resultados obtidos por SEM apoiaram aqueles obtidos por medidas eletroquímicas. A estrutura morfológica do pó de cobre depositado da solução a $20 \%$ (v/v) de DHP em 1000 rpm e 298 K foi notável, agregados cristalinos arredondados com espaços vazios.

The effect of different concentrations of 1,3-dihydroxypropane (DHP) on the electrodeposition of copper powder from acidified copper sulphate solution has been studied at different temperatures and different speeds of rotation. Copper powder was electrodeposited onto rotating cylinder electrode (RCE) that made of pure copper. The inhibition percentage, $\mathrm{P}$, in the electrodeposited copper powder was $0.00-92.91 \%$, depending on the experimental variables. $\mathrm{P}$ was affected by temperature and mole fraction of DHP, while rotation did not show any influence whatsoever. Values of the activation energy of electrodeposition process, $\mathrm{E}_{\mathrm{a}}$, were found to be less than $28 \mathrm{~kJ} \mathrm{~mol}^{-1}$ indicating diffusion controlled process. The overall mass transfer correlations under the present conditions have been obtained using the dimensional analysis method. The data were valid for $80<\mathrm{Sh}$ (Sh $=$ Sherwood number $)<3970$ $290<$ Sc $(\mathrm{Sc}=$ Schmidt number $)<59284$ and $271<\operatorname{Re}(\operatorname{Re}=$ Reynolds number $)<52705$ and the results agreed with the previous studies of mass transfer to rotating cylinders in turbulent flow regimes. Experimental determination of the solution critical velocity was obtained for blank and $20 \%(\mathrm{v} / \mathrm{v})$ DHP solutions at $298 \mathrm{~K}$. The effect of time, DHP content, temperature and the speed of rotation on the morphological changes of the electrodeposited copper powder as well as deposits composition and particle size have been studied. Various particle sizes ranged $60.5-203.4 \mathrm{~nm}$ were obtained, characterized by EDS and XRD and found to be pure copper with small amount of oxygen. Different topographs proved that the rate of copper electrodeposition increased by increasing time, temperature and the speed of rotation. In addition, they proved that the deposition rate decreased by adding DHP to the solution. Therefore, the results obtained by SEM supported those results obtained by electrochemical measurements. The morphological structure of deposited copper powder from 20\% (v/v) DHP at 1000 rpm and 298K was unique, rounded-crystalline aggregates with voids.

Keywords: 1,3-dihydroxypropane, copper powder, electrodeposition, rotating cylinder electrode

\footnotetext{
* e-mail: hsolman@link.net
} 


\section{Introduction}

The use of RCE, as a cathode reaction surface for metal electrodeposition or metal extraction, has proved successful for a wide range of applications. ${ }^{1}$ The RCE provides high rates of mass transport due to high rates of convectivediffusion in turbulent flow, ${ }^{2}$ as stated by Eisenberg et al. ${ }^{3}$ who found the relationship $\mathrm{Sh}=0.079 \mathrm{Re}^{0.7} \mathrm{Sc}^{0.356}$ to hold for the range $100<\operatorname{Re}<100,000$.

Copper is an intermediate metal, ${ }^{4}$ which has medium exchange current density $\left(10^{-5}\right.$ to $\left.1 \mathrm{~mA} \mathrm{~cm}^{-2}\right)$ and deposits at medium polarization. It deposits in very rough or powdery form when electrodeposition is carried out at the limiting current density. An addition agent is defined as any material, which is added to an electroplating bath for the specific purpose of modifying the physical properties of the deposit. Relatively small amounts of addition agent have large effect on the physical properties of deposits such as brightness, smoothness, hardness and ductility. Most addition agents are organic compounds, ${ }^{5,6}$ but, occasionally, inorganic materials are employed. ${ }^{7}$ Organic solvents are also employed in the electrodeposition of metals that cannot be electrodeposited directly from aqueous solutions. ${ }^{89}$ The importance of these media lies in the fact that changing their composition can vary their physicochemical properties. Bright copper has been electrodeposited from aqueous ammonia solutions. ${ }^{10}$ Electrodeposition of copper has been studied in presence of ethanol, n-propanol, iso-propanol and tert-butanol, ${ }^{11}$ and methanol, ethylene glycol and glycerol. ${ }^{12}$ Electrodeposition of nickel from mixed baths, ${ }^{13}$ and from nonaqueous baths, ${ }^{14}$ led to some promising results. In the case of mixed solvent bath, the change in physicochemical properties of the deposit is attributed to the change in solvent composition. Moreover, the effect of aprotic constituent, dielectric constant and state of solvation of ions to be electrodeposited can easily vary by simply changing the composition of the mixed solvents. During electrodeposition studies of copper and nickel from water-methanol bath, ${ }^{15}$ the change in electronic state of metal ion was attributed to the structural changes of solvent.

Compromising between the mass production and particle size is a challenging task in the industry of metallic powders and, given that, the microstructure and morphology of the electrodeposited metal are affected by the state of solvation; therefore, this work aims to investigate copper powder electrodeposition from acidified solutions of copper sulphate mixed with different contents of DHP under forced convection regime. Such investigation included change in temperature, rotation speed of RCE, and concentration of DHP. In addition, it aims to study the SEM topographs and EDS analysis to support the experimental measurements and to shed more light on copper powder production. Overall, this study is concerned with all possibilities to generate new ideas for understanding and prediction of the electrode and cell geometries through dimensionless correlations to reach the optimum conditions useful in the industry of copper powder.

\section{Experimental}

All chemicals were Analar grade and supplied by BDH chemicals Ltd. Solutions were prepared with water of resistivity $15-\mathrm{M} \Omega \mathrm{cm}$, which was obtained from a MilliRo/ MilliQ water purification system. Copper sulphate concentration and content were checked by the iodinethiosulphate method. ${ }^{11}$ The density and viscosity for all solutions, Table S1 (see Supplementary Information), were measured at 298, 303, 308 and $313 \mathrm{~K} .{ }^{11}$

A standard glass type cell with a polypropylene lid was used in all experiments. ${ }^{16}$ The solution volume was $1000 \mathrm{~mL}$. The polypropylene lid contained four inlets, which were used for working electrode WE immersion, luggin probe (reference electrode RE: saturated calomel electrode, SCE), counter electrode CE (copper) and thermometer to measure the temperature.

A $99.99 \%$ purity copper cylindrical sample was used as WE. This sample was rotated at controlled rates by an analytical rotator model A.S.R. made by PINE Instrument Company. The cylindrical samples of copper had dimensions of $8 \mathrm{~mm}$ height and $12 \mathrm{~mm}$ diameter. The specimens were lightly abraded with 1200 grade silicon carbide paper, washed with distilled water, acetone and deionised water and dried in a cool air stream prior to use. The anode CE, was machined from high purity (99.99\%), commercially available copper. In order to ensure a correct control of the specimen rotation rate and the correct recording of potentials, regular checking of the rotation rate was carried out.

The Potentiostat was Ministat Precision Potentiostat made by Thompson Electrochem Ltd. coupled to a Chemical Electronics (Birtley) Ltd. Sweep Generator and controlled by an 8086 Personal Computer via an Advantech PCL-718 Lab Card and a PCLD-780 wiring terminal board. In this system the Advantech Labtech Aquire software was used.

All electrochemical experiments and polarization curves were carried out using a potentiodynamic method. The sweep rate in all experiments was $1.67 \mathrm{mV} \mathrm{s}^{-1}$, which considered being suitable for copper electrodeposition. ${ }^{4}$

\section{Cathodic polarization}

The variables used in this investigation were rotation speed $(0-1000 \mathrm{rpm})$, temperature $(298-313 \mathrm{~K})$, and blank solution $\left(0.1 \mathrm{~mol} \mathrm{~L}^{-1} \mathrm{CuSO}_{4}\right.$ and $\left.1.5 \mathrm{~mol} \mathrm{~L}^{-1} \mathrm{H}_{2} \mathrm{SO}_{4}\right)$ without and with DHP $10-60 \%(\mathrm{v} / \mathrm{v})$ with a sweep range of $700 \mathrm{mV}$. 


\section{Determination of the critical velocity}

In these experiments, cathodic polarisation was used. The temperature was $298 \mathrm{~K}$ in all experiments and additive's concentration was 20\% (v/v) DHP besides the blank solution. The rotation range was 1500 to $7000 \mathrm{rpm}$. The experimental procedure and set up were similar to cathodic polarisation.

\section{Morphology and composition analyses}

An AMRAY 1810 Scanning Electron Microscope (SEM) was used to examine the surface topography of specimens after experiment, while Energy Dispersive $\mathrm{X}$-ray Analysis (EDS) was used for elemental analyses. The specimens were examined through an acceleration potential of $20 \mathrm{KeV}$; the specimens were coated with carbon to avoid electron charging of the surface since the surface film may not be electrically conductive.

Two types of specimens were prepared to examine the surface topography. The first type of specimens was used for free convection experiments, while the second type was used for forced convection ones. The free convection specimens were made of copper rods that were cut into small pieces of dimensions $0.8 \mathrm{~cm}$ height and $1.2 \mathrm{~cm}$ diameter; while those used for forced convection were made of copper cylinders with $0.8 \mathrm{~cm}$ in height and $1.2 \mathrm{~cm}$ in diameter. For all specimens, the surfaces for SEM analyses were polished with series of silicon carbide paper grades in the range 120 $1200 \mu \mathrm{m}$, then with $3 \mu \mathrm{m}$ diamond paste followed by $1 \mu \mathrm{m}$ diamond paste on a polishing wheel. After washing with deionised water and degreasing in acetone, warm air was blown over the surface. These specimens were stored in a desiccator over silica gel prior to use.

X-ray Diffraction (XRD) measurement for copper powder was carried out using a Shimazu XRD-7000 $\mathrm{X}$-ray Diffractometer with $\mathrm{Cu}-\mathrm{Ka} 1$ radiation operated at $40 \mathrm{kV}$ and $30 \mathrm{~mA}$, with a scan speed of $2 \theta \mathrm{min}^{-1}$.

Temperature, $298-313 \mathrm{~K}$; DHP content, $0-60 \%$ $(\mathrm{v} / \mathrm{v})$; rotation rate, 0 - $1000 \mathrm{rpm}$; and time, $10-30 \mathrm{~min}$, were the different variables that have been employed to study the surface analysis by EDS and XRD identification measurements.

\section{Results and Discussion}

\section{Cathodic polarisation}

Values of the limiting current densities, $\mathrm{I}_{1}$, for all solutions at different rotations and different temperatures using copper anode are given in Table S2 (see Supplementary Information).
Noticeably, the limiting current density decreases with increasing DHP mole fraction and increases by increasing temperature. The increase of mass transport under forced or turbulent conditions may refer to elevation in solution temperature, ${ }^{2}$ roughness of the deposit and/or the increase in agitation. Equation 1 was used to calculate the mass transfer coefficients, $\mathrm{k}$, for DHP solutions.

$\mathrm{k}=\frac{\mathrm{I}_{1}}{\mathrm{nFC}_{\mathrm{o}}}$

where $\mathrm{n}=$ number of electrons involved in the reaction, $\mathrm{F}$ $=$ Faraday constant $=96500\left(\mathrm{C} \mathrm{mol}^{-1}, \mathrm{C}=\mathrm{A} \mathrm{s}\right), \mathrm{C}_{\mathrm{o}}=$ bulk concentration of copper sulphate $\left(\mathrm{mol} \mathrm{cm}^{-3}\right)$.

It is clear in Table S2 and in Figure 1 that the limiting current density increases with increasing the speed of rotation, which proves that the electrodeposition process of copper in presence of DHP as well as in aqueous media is diffusion-controlled reaction.

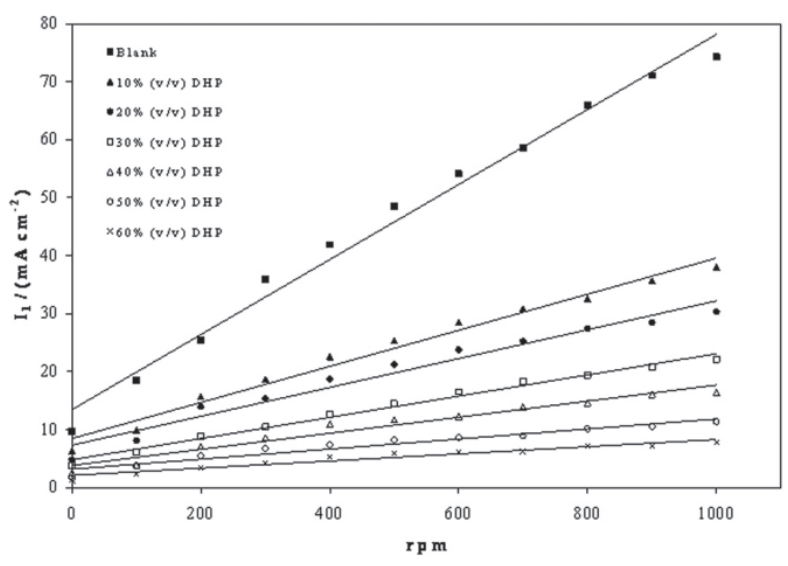

Figure 1. Variation of limiting current density, $\mathrm{I}_{\mathrm{l}}$, with the speed of rotation, rpm, at $298 \mathrm{~K}$.

The percentage of inhibition, $\mathrm{P}$, was calculated from equation 2. P caused by DHP was in the range of $0.00-92.91 \%$ depending on the concentration of DHP as well as the temperature.

$\mathrm{P}=\frac{\mathrm{I}_{\mathrm{l}_{\text {blank }}}-\mathrm{I}_{\mathrm{l}_{\text {DHP. }}}}{\mathrm{I}_{\mathrm{l}_{\text {blank }}}} \mathrm{X} 100$

Table S3 (see Supplementary Information) gives the values of $\mathrm{P}$, which shows that $\mathrm{P}$ increased as the mole fraction of DHP, X, increased, but it was not affected by rotation. This indicates that the rotation factor has little effect on the adsorption process and the decrease in mass transfer coefficient in this case is attributable to the increase in the interfacial viscosity, ${ }^{16}$ which caused by the adsorption of alcohol molecules at the cylinder surface with their nonpolar ends, while the polar ones are directed towards solution.

Figure 2 shows the cathodic polarisation curves for copper powder that electrodeposited from acid-sulphate solution with 
variable amounts of DHP at $298 \mathrm{~K}$ and zero rpm as an example. It is obvious that in alcohol-free solution the current at the beginning increases linearly, then as the cathodic potential increases it tends to exhibit limiting current plateau. The reduction of copper ions takes place through two steps: ${ }^{17}$

$$
\text { Step }{ }^{1}: \mathrm{Cu}^{2+}+e \stackrel{\text { Slow }}{\longrightarrow} C \mathrm{u}^{+} ; \text {Step }^{2}: \mathrm{Cu}^{+}+e \stackrel{\text { Fast }}{\longrightarrow} \mathrm{Cu}
$$

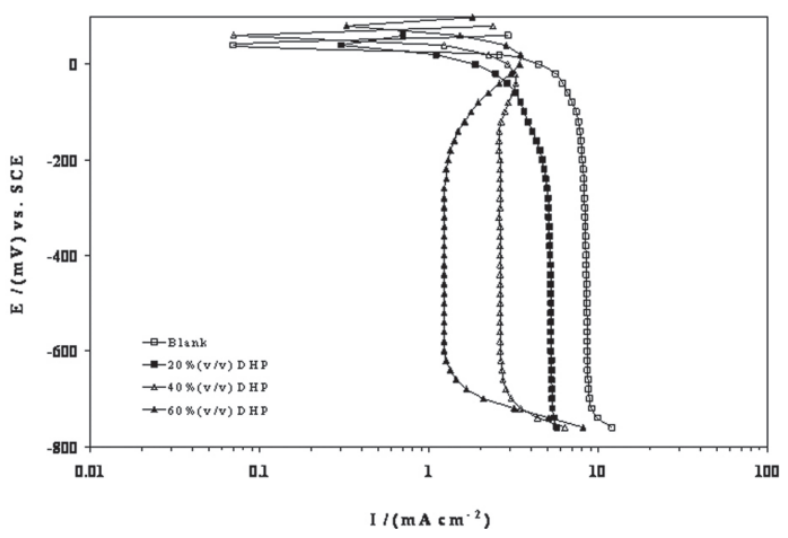

Figure 2. Typical potential - current curves obtained at 298K, no rotation, and different DHP contents.

It was assumed that the first step in this process occurred slowly and the rate was controlled by the equilibrium between $\mathrm{Cu}^{2+}$ and $\mathrm{Cu}^{+}$at the electrode surface. However, addition of alcohol to the sulphate solution increases the cathodic polarisation and decreases the value of the limiting current density. The observed changes in the cathodic polarisation in the presence of DHP suggest that it acts as an inhibitor, which is confirmed by the observation, at any given overpotential, the current density for copper deposition from solutions containing DHP is always lower than that for the blank solution. This inhibition effect may be due to the adsorption of alcohol molecules on the cathode surface and/or the complexation of $\mathrm{Cu}^{2+}$ with alcohol molecules. It is known that in acidic media, $\mathrm{Cu}^{2+}$ can complex with alcohol molecules via the alcohol hydroxyl groups and exists as a cationic complex. ${ }^{17}$

\section{Adsorption isotherms}

Adsorption isotherms are very important in determining the mechanism of organo-electrochemical reactions. The most frequently used isotherms are those of Langmuir, Frumkin, Parsons, Temkin, Flory-Huggins and BockrisSwinkels. All these isotherms are of the general form:

$f(\theta, x) \exp (-a \theta)=K_{e} C$

where , is the surface coverage, $\mathrm{K}_{\mathrm{e}}$ is the equilibrium constant, $C$ is the concentration of the electrolyte and $f(\theta, x)$ is the configurational factor that depends essentially on the physical model and assumptions underlying the derivation of the isotherm. The mechanism of electrodeposition inhibition is generally believed to be due to the formation and maintenance of an adsorbed film on the metal surface.

The surface coverage, $\theta$, can be determined using the following equation:

$\theta=1-\frac{\mathrm{I}_{\mathrm{DHP}}}{\mathrm{I}_{\text {Blank }}}$

where $I_{D H P}$ and $I_{\text {Blank }}$ are the limiting current densities in case of solvent and blank solutions; respectively.

Values of the equilibrium constant were computed and listed in Table S4 (see Supplementary Information) using Langmuir isotherm:

$\mathrm{K}_{\mathrm{e}} \mathrm{C}=\frac{\theta}{1-\theta}$

When $\log \frac{\theta}{1-\theta}$ was plotted versus $\log C$, straight lines were obtained with slopes nearly equal unity, which proves the fact that the adsorption of DHP on copper surface obeys the Langmuir adsorption isotherm. As a result, this leads to the suggestion that the adsorbed molecules do not interact with each other. In addition, straight lines were obtained when $\theta$ was plotted versus $\log \mathrm{C}$ at different temperatures, indicating that the adsorption of DHP on copper surface follows Temkin's adsorption isotherm as well.

The free energy of adsorption, $\Delta \mathrm{G}_{\text {ads }}$, at different temperatures was calculated and listed in Table S5 (see Supplementary Information) using the following equation:

$\mathrm{K}_{\mathrm{e}}=\frac{1}{55.5} \exp \left[\frac{-\Delta \mathrm{G}_{\mathrm{ads}}}{\mathrm{RT}}\right]$

The value of 55.5 is the concentration of water in solution expressed in mol L-1. The negative sign of $\Delta \mathrm{G}_{\text {ads }}$ values indicates the spontaneous adsorption of DHP molecules, which is usually characteristic for strong interaction with metal surface. From Table S5, values of $\Delta \mathrm{G}_{\text {ads }}$ are more positive than $-40 \mathrm{~kJ} \mathrm{~mol}^{-1}$, indicating physical adsorption on metal surface.

\section{Thermodynamic treatment of the results}

To investigate the mechanism of the electrodeposition process, the activation energies, $\mathrm{E}_{\mathrm{a}}$, of the process were calculated from the values of the limiting current density in absence and in presence of DHP at different temperatures according to Arrhenius equation:

$\ln \left(\mathrm{I}_{1}\right)=\ln (\mathrm{A})-\frac{\mathrm{E}_{\mathrm{a}}}{\mathrm{R}} \frac{1}{\mathrm{~T}}$ 
where $\mathrm{A}$ is a pre-exponential factor related to concentration, steric effects, metal surface characteristics, etc; $\mathrm{R}$ is the molar gas constant and $\mathrm{T}$ is the absolute temperature.

The activation energy of the process, $\mathrm{E}_{\mathrm{a}}$, is an important parameter for determining the rate-controlling step. If the rate-controlling step is the diffusion of aqueous species in the boundary layer then $\mathrm{E}_{\mathrm{a}}$ is generally $\leq 28 \mathrm{~kJ} \mathrm{~mol}^{-1}$, while $\mathrm{E}_{\mathrm{a}}$ is usually $>43 \mathrm{~kJ} \mathrm{~mol}^{-1}$ if adsorption of species on the reaction surface and subsequent chemical reaction takes place.

Values of activation energy, $\mathrm{E}_{\mathrm{a}}$, as well as the rest of thermodynamic parameters, enthalpy of activation, $\Delta \mathrm{H}^{*}$, entropy of activation, $\Delta S^{*}$, and free energy of activation, $\Delta \mathrm{G}^{*}$, were calculated and listed in Table S6 (see Supplementary Information).

Table $\mathrm{S} 6$ shows that all $\mathrm{E}_{\mathrm{a}}$ values are lower than 43 $\mathrm{kJ} \mathrm{mol}^{-1}$; characterizing diffusion processes are controlling the electrodeposition reaction. Figure 3 is a presentation of controlling the particle size as a parameter of two variables; the composition of DHP and the speed of rotation. As it is shown in Figure 3, the highest composition of DHP does not mean the lowest $\mathrm{E}_{\mathrm{a}}$ value and vice versa. This last observation is also applicable for forced convection regime.

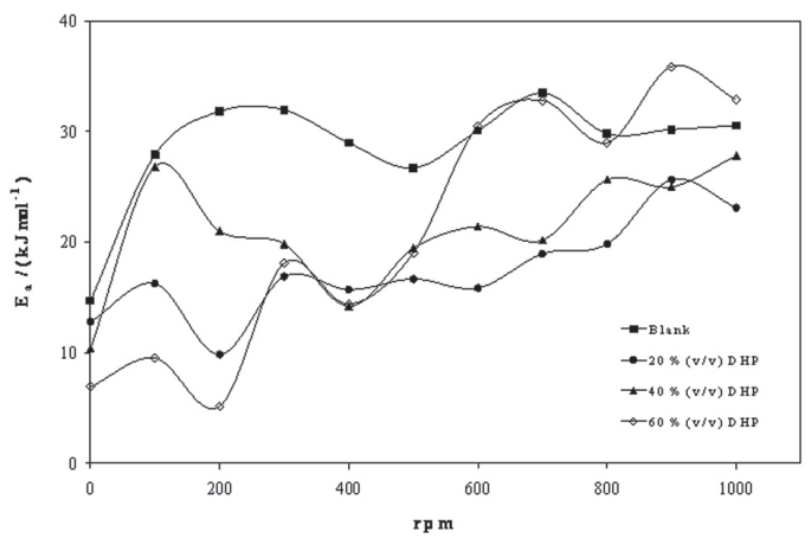

Figure 3. Variation of activation energy, $\mathrm{E}_{\mathrm{a}} /\left(\mathrm{k} \mathrm{J} \mathrm{mol}^{-1}\right)$, with the speed of rotation, rpm, at $298 \mathrm{~K}$.

From Table S6, it is also noticed that the weak dependence of $\Delta \mathrm{G}^{*}$ on the composition of the organic solvent can be attributable largely to the general linear compensation between $\Delta \mathrm{H}^{*}$ and $\Delta \mathrm{S}^{*}$ for the given temperature. The non linear variation of $\Delta \mathrm{S}^{*}$ with the mole fraction is a criterion of specific solvation where random distribution is not valid in the absence of strong hydrogen bonding between the molecules of water and the organic solvent. ${ }^{18}$

The plots of $\Delta \mathrm{H}^{*}$ versus $\Delta \mathrm{S}^{*}$, Figure 4 , for different solvent compositions at different speeds of rotation were found to be linear. The values of isokinetic temperature, $\beta$, were computed from the slope of such plots and found to be in the range $214.3-269.0 \mathrm{~K}$ indicating that mass transfer rate is entropy controlled, ${ }^{19}$ where the solute-solvent interaction plays an important role in the rate determining step.

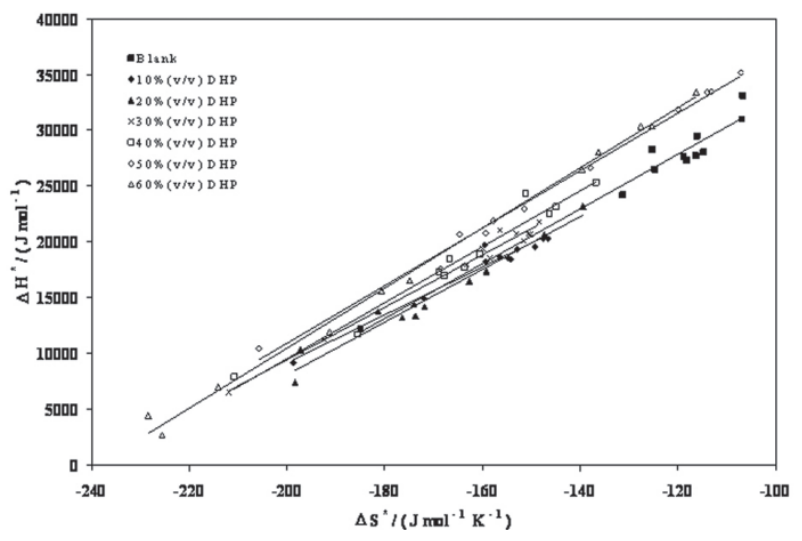

Figure 4. Variation of enthalpy of activation, $\Delta \mathrm{H}^{*} /\left(\mathrm{k} \mathrm{J} \mathrm{mol}^{-1}\right)$, with the entropy of activation, $\Delta \mathrm{S}^{*} /\left(\mathrm{J} \mathrm{mol}^{-1} \mathrm{~K}^{-1}\right)$.

\section{Effect of rotation}

The angular velocity, $\omega$, is given by equation 8 :

$\omega=\frac{2 \pi \mathrm{rpm}}{60}$

Figure 5 shows the relation between the limiting current density and the angular velocity to a power 0.7 at $298 \mathrm{~K}$ and different compositions of DHP. Straight lines were obtained and the limiting current density increases by increasing rotation, which indicates that the electrodeposition process of copper in presence of DHP as well as in aqueous media is diffusion-controlled reaction.

The diffusion coefficient of $\mathrm{Cu}^{2+}$ ions, $\mathrm{D}$, in different solutions was determined from the values of limiting current density, as shown in Table S7 (see Supplementary Information), using Eisenberg equation: ${ }^{3}$

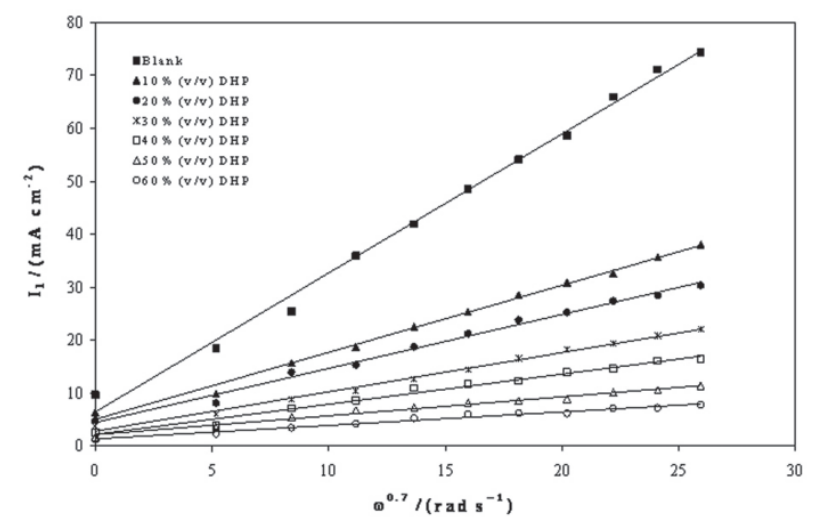

Figure 5. Variation of the limiting current density, $\mathrm{I}_{\mathrm{l}}$, with the angular velocity to a power $0.7, \mathrm{w}^{0.7}$, at $298 \mathrm{~K}$ using different DHP contents. 
$\mathrm{I}_{1}=0.0791 \mathrm{nFC}_{\mathrm{b}} \mathrm{U}^{0.7} \mathrm{~d}_{\mathrm{i}}^{-0.3} \mathrm{v}^{-0.344} \mathrm{D}^{0.644}$

where $\mathrm{C}_{\mathrm{b}}$ is the bulk concentration $\left(\mathrm{mol} \mathrm{cm} \mathrm{cm}^{-3}\right), \mathrm{U}$ is the peripheral velocity $=\omega \mathrm{r}$ in $\mathrm{cm} \mathrm{rad} \mathrm{s}^{-1}$ ( $\mathrm{r}$ is the radial distance in $\mathrm{cm}$ ) or $\mathrm{U}=2 \pi \omega \mathrm{r}$ in $\mathrm{cm} \mathrm{s}^{-1}, \mathrm{~d}$ is the characteristic length for the rotating cylinder in $\mathrm{cm}$, and $v$ is the kinematic viscosity in stoke $(v=\eta / \rho, \eta$ is the viscosity in $\mathrm{g} \mathrm{cm}^{-1} \mathrm{~s}^{-1}$ and $\rho$ is the density in $\mathrm{g} \mathrm{cm}^{-3}$ ).

The diffusion coefficient; $\mathrm{D}$, of $\mathrm{Cu}^{2+}$ ions in solutions containing alcohols decreases due to the increase in the interfacial viscosity, $\eta$ in accordance with de StokesEinstein equation: ${ }^{20}$

$\frac{\eta \mathrm{D}}{\mathrm{T}}=$ const

The present results agree with the polarographic studies conducted in solutions containing surfactants where it was found that the diffusion current decreases in the presence of surfactants. ${ }^{21,22}$

Table S7 illustrates the slight decrease in the values of the diffusion coefficient, D, in presence of DHP, which indicate that DHP hinders the diffusion of cupric ions from the bulk to the outer limit of the electrode double layer. A possible explanation is that DHP is a polar molecule with interfacial activity that could change the composition and the properties of the double layer on the electrode surface. Thus, DHP molecules replace the water molecules on the metallic surface, forming an adsorbed superficial film. This would increase the electrolyte viscosity and lower the dielectric constant at the electrode/electrolyte interface. ${ }^{23}$ Consequently, hydrated metal ions or complex ions approach the surface with increased difficulty to enable charge transfer.

It was noted in a previous review, ${ }^{24}$ that mass transport to an inner RCE in turbulent flow system may be described by empirical dimensionless correlations of the form:

$\mathrm{Sh}=\mathrm{a} \operatorname{Re}^{\mathrm{b}} \cdot \mathrm{Sc}^{\mathrm{c}}$

where $\mathrm{Sh}, \mathrm{Re}$ and $\mathrm{Sc}$ are the Sherwood ( $\mathrm{Sh}=\mathrm{kl} / \mathrm{D})$, Reynolds $(\mathrm{Re}=\mathrm{lU} / v)$ and Schmidt $(\mathrm{Sc}=\mathrm{y} / \mathrm{D})$ numbers; respectively and $\mathrm{a}$ and $\mathrm{b}$ are empirical constants, $\mathrm{c}=0.33$; indicating forced convection regime. ${ }^{1}$ Table S8 (see Supplementary Information) summarizes the values of dimensionless groups (Sh, Sc and $\mathrm{Re}$ ) at all experimental conditions. By plotting $\log \left[\frac{\mathrm{Sh}}{\mathrm{Sc}^{0.33}}\right]$ against $\log (\mathrm{Re})$, a straight line was obtained its slope gave the constant $b$ while the intercept offered the other constant a, Table S9 (see Supplementary Information). Values of constants $a$ and $b$ depend on: ${ }^{24}(i)$ the type of roughness, (ii) the degree of roughness, and (iii) the electrolyte composition, temperature and the morphology of the deposits.

In this study, a forced convection mechanism is obtained which agrees very well with the relationship $\mathrm{Sh}=0.0791 \mathrm{Re}^{0.7} \mathrm{Sc}^{0.356}$ given by Eisenberg et al. ${ }^{25}$ for mass transfer to a rotating cylinder in turbulent flow system and exponents in all equations denote a highly turbulent flow, which agrees with the previous mass transfer study in aqueous media. ${ }^{26}$ Also, results at hand agree excellently with $\mathrm{Sh}=1.581 \mathrm{Re}^{0.725} \mathrm{Sc}^{0.33}$ given by Mamdouh et al. ${ }^{27}$ for mass transfer during cementation using rotating cylinder in an aqueous medium as well as with the equation $\mathrm{Sh}=0.061 \mathrm{Re}^{0.833} \mathrm{Sc}^{0.33}$ given by Ahmed et al. ${ }^{28}$ for mass transfer during copper cementation from alcoholic-water mixtures using rotating cylinder in turbulent system.

\section{Determination of the critical velocity}

To evaluate whether the limiting current increases indefinitely with increasing the speed of rotation or there is a limit for such increase, two solutions were chosen, one of them was the blank solution and the other was $20 \%(\mathrm{v} / \mathrm{v})$ DHP. Polarisations were carried out at high speeds of rotation and 298 K. Figure 6 shows the relation between the limiting current density and the angular velocity, $\omega$, to a power 0.7 for blank and 20\% (v/v) DHP solutions at $298 \mathrm{~K}$ and high speeds of rotation. It is shown in Table S10 (see Supplementary Information) that the critical velocity in case of blank solution in the range of $5000-6000 \mathrm{rpm}$ with average critical limiting current density of $148.91 \mathrm{~mA} \mathrm{~cm}^{-2}$, while for $20 \%(\mathrm{v} / \mathrm{v})$ DHP solution it was $5500-7000 \mathrm{rpm}$ with average limiting current density of $101.34 \mathrm{~mA} \mathrm{~cm}$. Currently, it is clear that the presence of DHP in the medium increases the critical velocity and decreases the critical limiting current density. This leads to conclude that the presence of DHP in copper electrodeposition bath will offer a faster surface diffusion process compared with electron

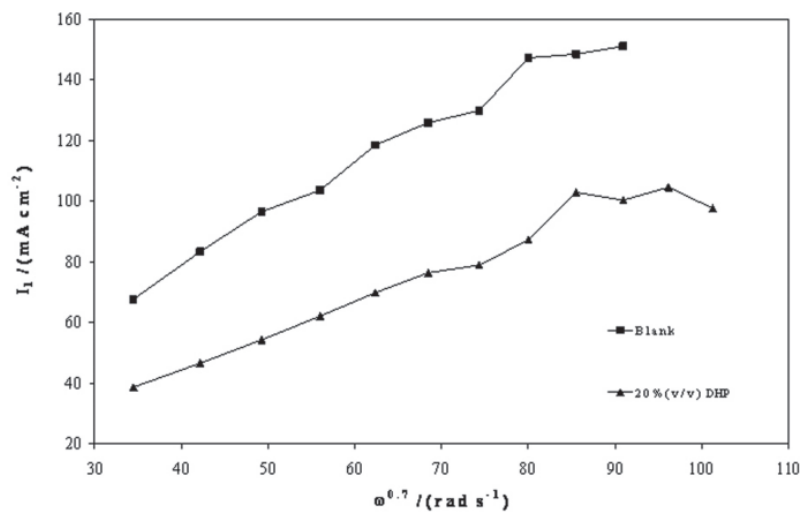

Figure 6. Variation of the limiting current density, $\mathrm{I}_{1}$, with the angular velocity to a power $0.7, \omega^{0.7}$, at high speeds of rotation and $298 \mathrm{~K}$. 
transfer and as a result the formation of adatoms and both crystal lattices and surface features will be well formed. ${ }^{29}$ It can be noticed from Figure 6 that the limiting current density increases by increasing rotation until we reach a certain region at which the current keeps almost constant, this is again the region of the critical velocity. Then the data at high speeds of rotation can be correlated by the equation, $\mathrm{Sh}=$ $0.1022 \mathrm{Re}^{0.705} \mathrm{Sc}^{0.33}$ as previously shown.

From the previous study concerning the electrodeposition process of copper powder in acidified solutions of copper sulphate and in the presence of DHP using the rotating cylinder electrode (RCE) the data were valid for $80<\mathrm{Sh}<$ $3970,290<\mathrm{Sc}<59284$ and $271<\operatorname{Re}<52705$.

\section{Morphology and composition analyses}

Since the concern was mainly the production of copper powder, all experiments were carried out at the limiting current that was determined for each solution, so it is expected that the morphologies of electrodeposited copper powder must be characterised by 3-D nucleation. ${ }^{7}$ The phenomenon of dendritic growth, ${ }^{29}$ may occur if the rate of the electrodeposition process is partially diffusion controlled, so, on a microrough surface, the rate of deposition at surface peaks will be greater than that at troughs. These surface nonuniformities, therefore, become more pronounced resulting, eventually, in the formation of macrorough deposits. The phenomenon of dendritic growth may also be related to differences in the rate of diffusion at different points on a surface. In the case of macrospiral growth, for instance, spherical diffusion to the tip of the spiral results in a higher rate of mass transport to this point and this may lead to dendritic growth.

All experiments were proceeded at $298 \mathrm{~K}$ with duration time of 20 minutes using copper anode and copper was electrodeposited onto copper cylinder with variation in the speed of rotation between 200 and 1000 rpm. Although it was stated, ${ }^{30}$ that an increase in copper ion concentration or in agitation will increase the particles size and obscures their dendritic character, it was found dramatic changes occurred when rotation started, dendrite nodules were formed with high degree of discontinuity as well as very rough deposits as in case of blank solution at $200 \mathrm{rpm}$, Figure $7 \mathrm{a}$.

Contrary to Figure $7 \mathrm{a}$ at $200 \mathrm{rpm}$, grape-like aggregates were formed with low degree of discontinuity at $1000 \mathrm{rpm}$ in case of blank solution, as shown in Figure 7b. Figure 7c represents the third type of morphology in this study in case of $20 \%$ (v/v) DHP at $1000 \mathrm{rpm}$, which is rounded-crystalline aggregates with voids. The main reason for voids formation is attributable to the swelling effect that correlates with the liberation of gases. ${ }^{31}$ This structure is considered as a unique surface feature in this study, although case of $10 \%(\mathrm{v} / \mathrm{v})$ DHP tends to give similar structure.

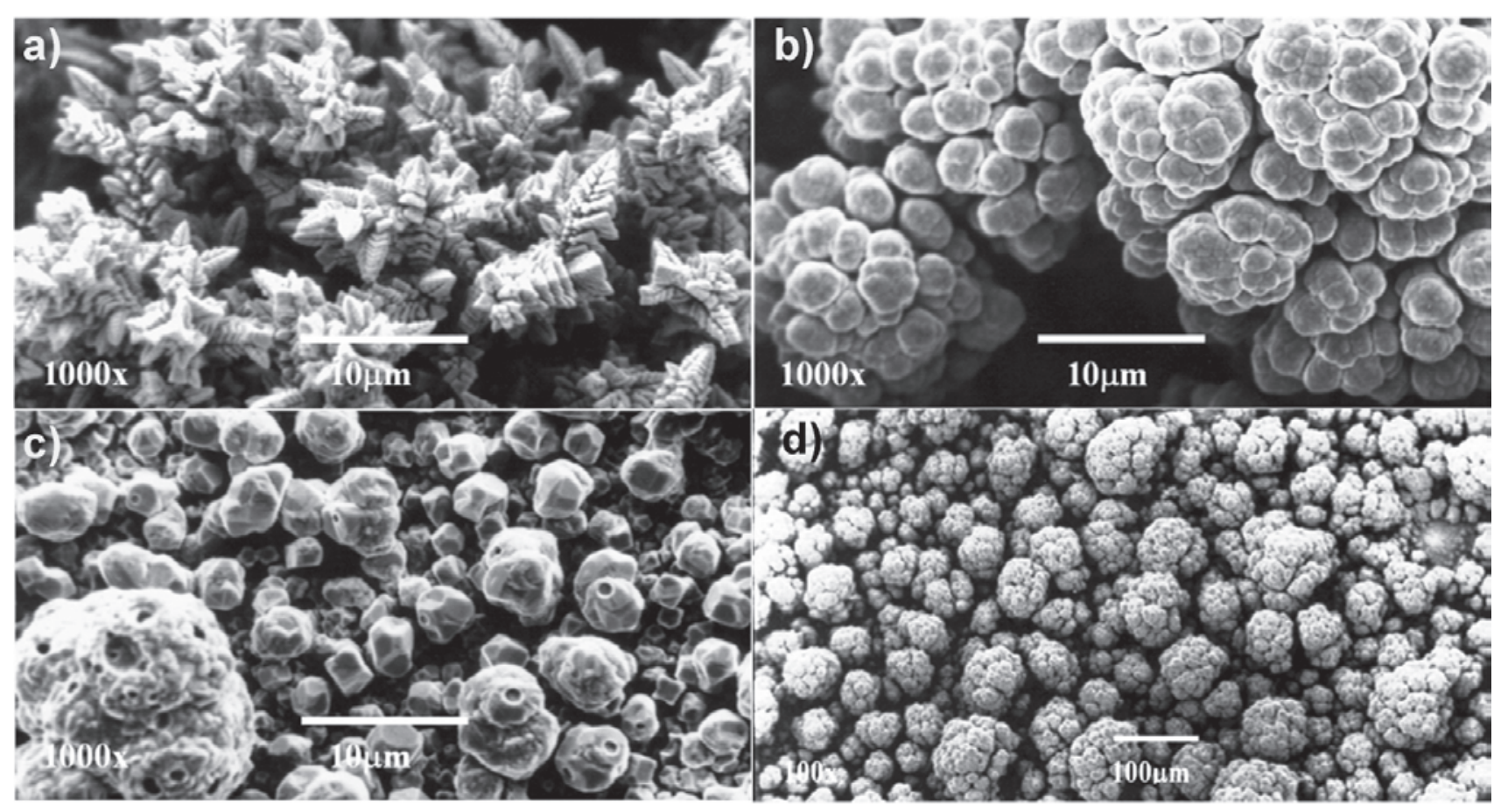

Figure 7. Electrodeposited copper in case of blank solution after 20 minutes a) at $25-26 \mathrm{~mA} \mathrm{~cm}^{-2}, 298 \mathrm{~K}$ and $\left.200 \mathrm{rpm}, \mathrm{b}\right)$ at $74-75 \mathrm{~mA} \mathrm{~cm}-2,298 \mathrm{~K}$ and $1000 \mathrm{rpm}, \mathrm{c}$ ) at $30-31 \mathrm{~mA} \mathrm{~cm}^{-2}, 298 \mathrm{~K}$ and $1000 \mathrm{rpm}$, and d) at $54-55 \mathrm{~mA} \mathrm{~cm}^{-2}, 298 \mathrm{~K}$ and $600 \mathrm{rpm}$. 
At $600 \mathrm{rpm}$ for all solutions, except 20\% (v/v) DHP, a transient structure between dendrite nodules and grapelike aggregates was formed, which means that the region between $200-600 \mathrm{rpm}$ is considered as a transient region with mixed deposition mechanisms as shown in Figure $7 \mathrm{~d}$ in case of blank solution.

High current densities or high cathodic overpotentials, accompanied by fast stirring rates can adversely affect electrodeposition process resulting in brittle deposits, which can comprise occlusions of additives and/or foreign materials. ${ }^{32}$ Figure 8 gives the EDS analysis for some chosen specimens that represent most of the experimental conditions. The analysis indicated that the composition of the electrodeposited copper powder under different conditions for all solutions was mainly pure copper (80.24 at.\%) and oxygen (19.37 at.\%) with tiny percentage of silicon and carbon, which may be due to the occlusion of foreign materials, ${ }^{32}$ on one hand. On the other hand, the presence of silicon could be attributable to the attendance of some glass leftover from another specimen, while carbon is referable to the coating of specimen with carbon before the analysis. In addition, oxygen peak in Figure 8 might caused by the oxidation of a negligible part of the deposit due to the high voltage used in the analysis. Figure 9 represents the distribution of both copper and oxygen in the produced powder under different conditions, showing the mutual homogeneous distribution of copper and oxygen.

XRD patterns of the deposited copper powder are presented in Figure 10 as an example. This exhibits polycrystalline copper in as deposited state with (111) as prominent plane parallel to the substrate. According to the standard PDF card (No. 04-0836), ${ }^{33}$ all of the

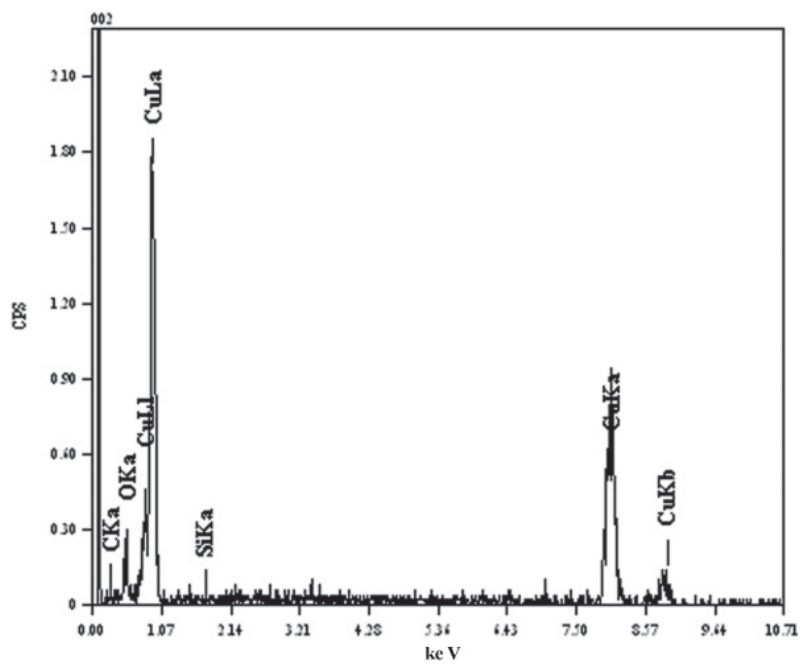

Figure 8. Deposit EDS analysis at different experimental conditions. a)

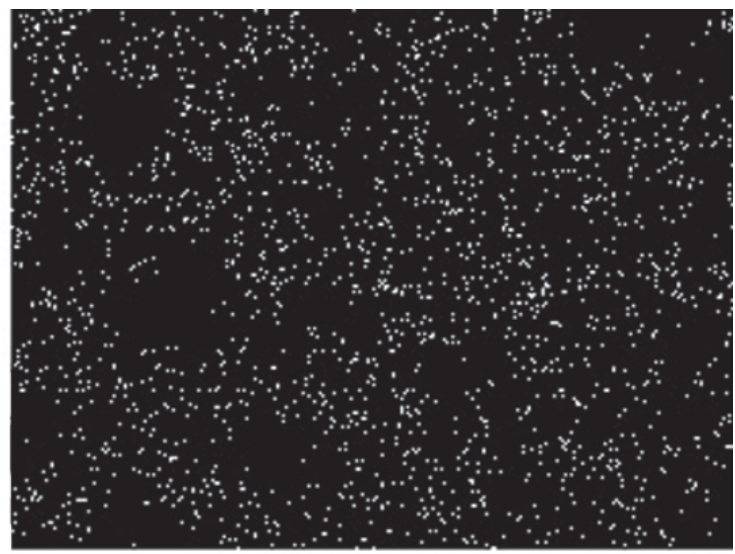

$300 \mu \mathrm{m}$ Cu K

b)

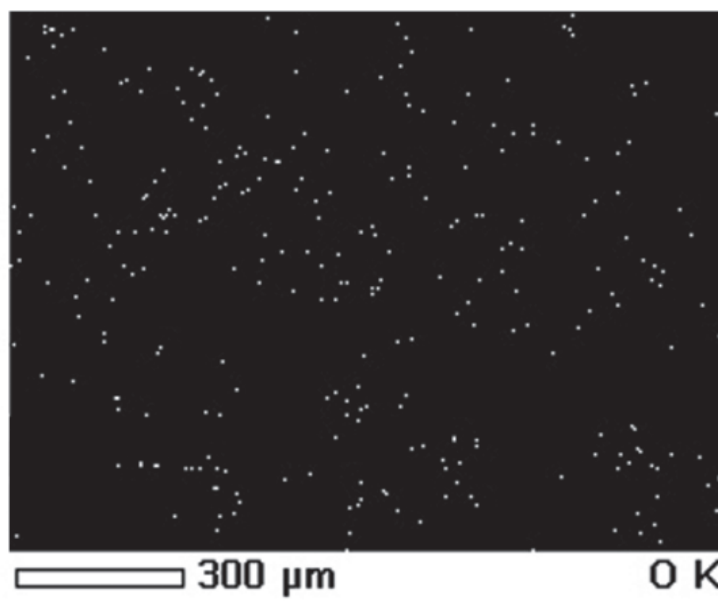

Figure 9. Atomic distribution of a) $\mathrm{Cu} \mathrm{K}$ and b) $\mathrm{O} \mathrm{K}$.

detected peaks are indexed as those from the cubic crystal [space group Fm3m (225)] with small two peaks that patterned for $\mathrm{Cu}_{2} \mathrm{O}$. The average particle size was calculated using Scherrer's equation:

$\mathrm{D}=\frac{0.9 \lambda}{\mathrm{B} \cos \theta_{\mathrm{B}}}$

where $\mathrm{D}$ is the particle size in $\mathrm{nm}, \lambda$ is the wave length of $\mathrm{X}$-ray radiation source $(\mathrm{Cu} \mathrm{Ka} 1, \lambda=1.54056)$, B is the full-width at half maximum and $\theta$ is the angle.

The average particle size of copper powder electrodeposited in absence of DHP was ranged between 127 $\mathrm{nm}$ at $1000 \mathrm{rpm}$ and $132.8 \mathrm{~nm}$ at $0 \mathrm{rpm}$, except at 600 rpm which was $83.8 \mathrm{~nm}$, supporting the hypothesis of transient mechanism at that rotation speed. Contrary to the blank solution, the average particle size in presence of DHP was $60.5 \mathrm{~nm}$ at all rotation speeds and all concentrations, except at $1000 \mathrm{rpm}$ and $20 \%$ (v/v) DHP which was $203.4 \mathrm{~nm}$, proving the unique structure of the deposited copper powder from that concentration. 


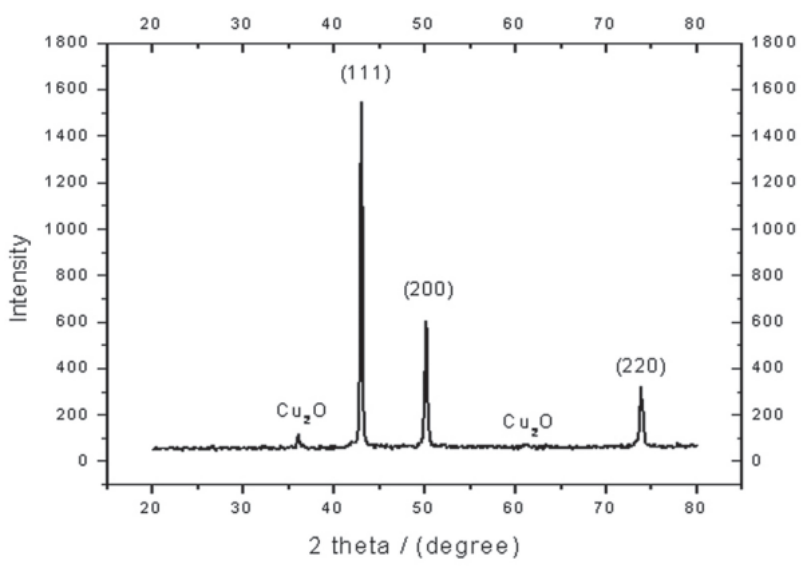

Figure 10. XRD patterns of as deposited $\mathrm{Cu}$ powder at different experimental conditions.

\section{Conclusions}

From the previous study concerning the electrodeposition process of copper powder in acidified solutions of copper sulphate and in the presence of DHP using the rotating cylinder electrode (RCE) the data were valid for $80<\mathrm{Sh}<3970,290<\mathrm{Sc}<59284$ and $271<\operatorname{Re}<52705$ with overall dimensionless correlation of $\mathrm{Sh}=0.1022 \mathrm{Re}^{0.705} \mathrm{Sc}^{0.33}$. Addition of DHP to the sulphate electrodeposition bath increases the cathodic polarisation and decreases the value of the limiting current density, while it increases with increasing temperature and the speed of rotation. The percentage of inhibition, $\mathrm{P}$, was in the range 0.00 $92.91 \%$ depending on the concentration of DHP as well as the temperature. The adsorption of DHP on copper surface was found to be physical adsorption and obeyed both Langmuir and Temkin adsorption isotherms. The mass transfer rate was found to be entropy controlled with diffusion process controlling the electrodeposition. The range of the critical velocity in case of blank solution was $5000-6000 \mathrm{rpm}$ with average critical limiting current density of $148.91 \mathrm{~mA} \mathrm{~cm}^{-2}$, while it was $5500-7000 \mathrm{rpm}$ for $20 \%$ (v/v) DHP solution with average limiting current density of $101.34 \mathrm{~mA} \mathrm{~cm}^{-2}$.

3-D dendritic structures were formed when the electrodeposition was carried out at the limiting current density with various particle sizes ranged $60.5-203.4$ $\mathrm{nm}$. EDS elemental analysis and XRD diffraction patterns indicated that the formed powder was mainly copper (80.24 at.\%) and oxygen (19.37 at.\%) with traces of carbon $(0.35$ at. $\%)$ and silicon $(0.04$ at. \%). The morphological structure of deposited copper from $20 \%$ $(\mathrm{v} / \mathrm{v})$ DHP at $1000 \mathrm{rpm}$ and 298K was unique, roundedcrystalline aggregates with voids.

\section{Supplementary Information}

Tables S1 to S10 are available free of charge as PDF file at http://jbcs.sbq.org.br

\section{References}

1. Gabe, D.R.; Walsh, F.C.; J. Appl. Electrochem. 1983, 13, 3.

2. Gabe, D.R.; Walsh, F.C.; The Reinhardt Schuhmann International Symposium on Innovative Technology and Reactor Design in Extraction Metallurgy, Colorado Springs, Colorado, USA, 1986, p. 775.

3. Eisenberg, M.; Tobias, C.W.; Wilke, C.R.; J. Electrochem. Soc. 1954, 101, 306.

4. Winand, R.; Application of Polarisation Measurements in the Control of Metal Deposition, Warren, I. H., ed., Elsevier Science Publishers: Amsterdam, 1984, p. 47.

5. Muresan, L.; Varvara, S.; Maurin, G.; Dorneanu, S.; Hydrometallurgy 2000, 54, 161.

6. Kelly, J.J.; Tian, C.Y.; West, A.C.; J. Electrochem. Soc. 1999, 146, 2540.

7. Andersen, T.N.; Pitt, C.H.; Livingston, L.S.; J. Appl. Electrochem. 1983, 13, 429.

8. Biallazor, S.; Lisowska-Oleksiak, A.; J. Appl. Electrochem. 1990, 20, 590.

9. Kumbhar, P.P.; Lokhande, C.D.; Ind. J. Chem. Technol. 1994, 1, 194.

10 Ibrahim, M.A.M.; Plat. Surf. Finish. 2000, 87, 67.

11 Selim, I.Z.; El-Sobki, K.M.; Khedr, A.A.; Soliman, H.M.A.; Bull. Electrochem. Ind. 2000, 16, 315.

12 Soliman, H.M.A.; Medium Effect on Mass Transfer Coefficient in Electrodeposition Process of Copper from Acidic Copper Sulfate Solutions, Ph.D. Thesis submitted for Faculty of Science, Alexandria University, Egypt, 1998.

13 Tikoo, P.K.; Singh, V.B.; Sultan, S.; Plat. Surf. Finish. 1984, $71,64$.

14 Bahadur, L.; Singh, V.B.; Tikoo, P.K.; J. Electrochem. Soc. 1981, 128, 2518.

15 Srivastava, H.K.; Tikoo, P.K.; Surf. Coat. Technol. 1987, 31, 343.

16 Selim, I.Z.; Ahmed, A.M.; Khedr, A.A.; Soliman, H.M.A.; Bull. Electrochem. Ind. 2001, 17, 27.

17 Abd El Rehim, S.S.; Sayyah, S.M.; El Deeb, M.M.; Appl. Surf. Sci. 2000, 165, 249.

18 Ismail, A.M.; El-Naggar, G.A.; Ahmed, A.M.; Bull. Electrochem. Ind. 2001, 17, 385.

19 El Shazly, Sh.A.; Massoud, S.S.; Zaghloul, A.A.; Mohamed, M.T.; Amira, M.F.; Bull. Soc. Chim. 1989, 6, 780.

20 Taha, A.A.; Sallam, S.H.; Ahmed, A.M.; Anti-Corros. Methods Mater. 1994, 41, 10.

21 Issa, I.M.; Ghoneim, M.M.; El-Samahy, A.A.; Tharwat, M.; Electrochim. Acta 1972, 17, 1251. 
22 Beck, T.R.; Alkire, R.C.; J. Electrochem. Soc. 1979, 126 , 1662.

23 Franklin, T.C.; Williams, T.; Narayan, T.S.N.; Guhl, R.; Hair, G.; J. Electrochem. Soc. 1997, 144, 3064.

24 Gabe, D.R.; Wilcox, G.D.; J. Appl. Electrochem. 1998, 28, 759.

25 Eisenberg, M.; Tobias, C.W.; Wilke, C.R.; J. Electrochem. Soc. 1955, 102, 415.

26 Pickett, D.; Electrochemical Reactor Design, Elsevier: Amsterdam, 1977, p. 110.

27 Nasser, A. Mamdouh; Fadalli, Olfat A.; Sedahmed, Gomaa H.; Metallkde 1989, 80, 60.
28 Abdel-Rahman, Hanaa H.; Kinetic Studies of Cementation of Copper on Rotating Zinc Cylinder in Aqueous and Mixed Solvents, Ph.D. Thesis submitted for Faculty of Science, Alexandria University, Egypt, 1998.

29 Pletcher, D.; Walsh, F.C.; Industrial Electrochemistry, Chapman and Hall, 1989, p. 216.

30 Russev, D.R.; J. Appl. Electrochem. 1981, 11, 177.

31 Walker, R.; Duncan, S.J.; Surf. Coat. Technol. 1986, 27, 137.

32 Hope, G.A.; Brown, G.M.; Schweinsberg, D.P.; Shimizu, K.; Kobayashi, K.; J. Appl. Electrochem. 1995, 25, 890.

33. Natl. Bur. Stand. (U.S.) 1953, Circ.539, 115.

Received: July 26, 2005

Published on the web: May 16, 2006 


\title{
The Use of Rotating Cylinder Electrode to Study the Effect of 1,3 Dihydroxypropane on the Production of Copper Powder
}

\author{
H.M.A. Soliman ${ }^{*, a}$ and H.H. Abdel-Rahman ${ }^{b}$ \\ ${ }^{a}$ Institute of New Materials and Advanced Technologies, Mubarak City for Scientific Research and Technology \\ Applications, New Borg El-Arab City, P.O. Box 21934 Alexandria, Egypt \\ ${ }^{b}$ Chemistry Department, Faculty of Science, Alexandria University, P.O. Box 426, Ibrahimia 21321, Alexandria, Egypt
}

Table S1. Viscosities and densities for all solutions at different temperatures

\begin{tabular}{lccc}
\hline & $\begin{array}{c}\text { Temperature, } \\
\text { T (K) }\end{array}$ & $\begin{array}{l}\text { Viscosity, } \\
\eta(\text { poise })\end{array}$ & $\begin{array}{c}\text { Density, } \\
\left.\text { ( } \mathrm{g} \mathrm{cm}^{-3}\right)\end{array}$ \\
\hline Blank, 0\% (v/v) DHP & 298 & 0.01084 & 1.09928 \\
& 303 & 0.00972 & 1.09647 \\
& 308 & 0.00879 & 1.09365 \\
10\% (v/v) DHP & 313 & 0.00800 & 1.09084 \\
& 298 & 0.01129 & 1.10656 \\
& 303 & 0.01013 & 1.10373 \\
& 308 & 0.00915 & 1.10090 \\
$20 \%$ (v/v) DHP & 313 & 0.00833 & 1.09807 \\
& 298 & 0.01304 & 1.11484 \\
& 303 & 0.01169 & 1.11199 \\
$30 \%$ (v/v) DHP & 308 & 0.01056 & 1.10913 \\
& 313 & 0.00961 & 1.10628 \\
& 298 & 0.01543 & 1.12810 \\
& 303 & 0.01384 & 1.12522 \\
$40 \%$ (v/v) DHP & 308 & 0.01250 & 1.12233 \\
& 313 & 0.01138 & 1.11945 \\
& 298 & 0.01879 & 1.13638 \\
& 303 & 0.01685 & 1.13348 \\
$50 \%$ (v/v) DHP & 308 & 0.01523 & 1.13057 \\
& 313 & 0.01386 & 1.12766 \\
& 298 & 0.02334 & 1.14865 \\
& 303 & 0.02093 & 1.14571 \\
& 308 & 0.01892 & 1.14277 \\
& 313 & 0.01721 & 1.13984 \\
& 298 & 0.02964 & 1.15793 \\
& 303 & 0.02658 & 1.15497 \\
& 308 & 0.02402 & 1.15200 \\
& 313 & 0.02186 & 1.14904 \\
\hline
\end{tabular}

* e-mail: hsolman@link.net 
Table S2. Values of the limiting current density, $\mathrm{I}_{1} /\left(\mathrm{mA} \mathrm{cm}^{-2}\right)$, for all solutions at different temperatures and different speeds of rotation

\begin{tabular}{|c|c|c|c|c|c|c|c|c|c|c|c|}
\hline & $\mathrm{rpm}$ & $298 \mathrm{~K}$ & $303 \mathrm{~K}$ & $308 \mathrm{~K}$ & $313 \mathrm{~K}$ & & $\mathrm{rpm}$ & $298 \mathrm{~K}$ & $303 \mathrm{~K}$ & $308 \mathrm{~K}$ & $313 \mathrm{~K}$ \\
\hline \multirow[t]{11}{*}{ Blank, 0\% (v/v) DHP } & 0 & 9.70 & 10.80 & 11.76 & 12.93 & $30 \%$ (v/v) DHP (cont.) & & & & & \\
\hline & 100 & 18.51 & 26.01 & 30.82 & 33.78 & & 600 & 16.50 & 19.12 & 22.15 & 26.49 \\
\hline & 200 & 25.41 & 35.73 & 37.01 & 54.00 & & 700 & 18.33 & 21.05 & 23.94 & 27.58 \\
\hline & 300 & 35.88 & 45.52 & 55.40 & 66.77 & & 800 & 19.36 & 23.39 & 26.28 & 30.66 \\
\hline & 400 & 41.89 & 53.51 & 61.62 & 74.48 & & 900 & 20.77 & 24.22 & 27.66 & 32.70 \\
\hline & 500 & 48.51 & 60.88 & 64.67 & 84.45 & & 1000 & 22.08 & 26.35 & 29.42 & 34.59 \\
\hline & 600 & 54.12 & 71.92 & 80.61 & 99.41 & $40 \%(\mathrm{v} / \mathrm{v}) \mathrm{DHP}$ & 0 & 2.56 & 2.59 & 2.80 & 3.12 \\
\hline & 700 & 58.63 & 73.78 & 96.56 & 109.97 & & 100 & 3.89 & 5.75 & 6.20 & 6.73 \\
\hline & 800 & 65.92 & 82.96 & 98.05 & 118.30 & & 200 & 7.11 & 7.64 & 9.18 & 10.51 \\
\hline & 900 & 71.07 & 87.87 & 111.13 & 125.64 & & 300 & 8.62 & 9.39 & 10.79 & 12.62 \\
\hline & 1000 & 74.27 & 96.34 & 112.74 & 135.79 & & 400 & 10.93 & 12.27 & 12.93 & 14.58 \\
\hline \multirow[t]{11}{*}{$10 \%(\mathrm{v} / \mathrm{v}) \mathrm{DHP}$} & 0 & 6.32 & 6.92 & 7.27 & 7.99 & & 500 & 11.74 & 12.79 & 14.44 & 17.14 \\
\hline & 100 & 9.93 & 11.95 & 13.16 & 15.50 & & 600 & 12.27 & 14.33 & 16.05 & 18.71 \\
\hline & 200 & 15.68 & 18.12 & 19.36 & 22.29 & & 700 & 13.91 & 15.80 & 17.45 & 20.78 \\
\hline & 300 & 18.69 & 21.98 & 24.90 & 27.97 & & 800 & 14.61 & 17.00 & 20.50 & 23.83 \\
\hline & 400 & 22.57 & 26.97 & 29.52 & 34.48 & & 900 & 16.09 & 18.26 & 22.67 & 25.62 \\
\hline & 500 & 25.34 & 30.97 & 34.52 & 39.06 & & 1000 & 16.44 & 18.78 & 23.65 & 27.68 \\
\hline & 600 & 28.55 & 33.69 & 37.68 & 43.23 & $50 \%(\mathrm{v} / \mathrm{v}) \mathrm{DHP}$ & 0 & 1.65 & 1.72 & 1.84 & 2.13 \\
\hline & 700 & 30.86 & 36.89 & 41.71 & 46.43 & & 100 & 3.68 & 4.17 & 4.91 & 5.74 \\
\hline & 800 & 32.57 & 40.58 & 45.16 & 51.26 & & 200 & 5.47 & 5.50 & 7.51 & 8.34 \\
\hline & 900 & 35.68 & 43.16 & 48.57 & 55.08 & & 300 & 6.73 & 7.67 & 9.60 & 10.29 \\
\hline & 1000 & 38.02 & 46.05 & 51.33 & 59.76 & & 400 & 7.32 & 8.06 & 10.50 & 11.59 \\
\hline \multirow[t]{11}{*}{$20 \%$ (v/v) DHP } & 0 & 4.82 & 5.08 & 5.75 & 6.09 & & 500 & 8.20 & 8.76 & 10.54 & 11.87 \\
\hline & 100 & 8.13 & 8.89 & 10.13 & 11.03 & & 600 & 8.59 & 9.81 & 12.27 & 14.91 \\
\hline & 200 & 13.94 & 14.44 & 15.65 & 16.79 & & 700 & 8.90 & 10.76 & 13.64 & 17.22 \\
\hline & 300 & 15.31 & 16.48 & 18.59 & 21.17 & & 800 & 10.13 & 11.63 & 15.27 & 20.03 \\
\hline & 400 & 18.72 & 19.26 & 22.07 & 25.11 & & 900 & 10.51 & 12.72 & 16.42 & 20.93 \\
\hline & 500 & 21.20 & 24.34 & 26.55 & 29.46 & & 1000 & 11.35 & 13.46 & 16.46 & 23.89 \\
\hline & 600 & 23.77 & 26.18 & 29.12 & 32.27 & $60 \%(\mathrm{v} / \mathrm{v}) \mathrm{DHP}$ & 0 & 1.23 & 1.23 & 1.30 & 1.40 \\
\hline & 700 & 25.21 & 29.59 & 32.00 & 36.91 & & 100 & 2.35 & 2.56 & 2.78 & 2.80 \\
\hline & 800 & 27.38 & 30.53 & 34.27 & 40.39 & & 200 & 3.45 & 3.65 & 3.72 & 3.83 \\
\hline & 900 & 28.45 & 33.07 & 37.58 & 47.38 & & 300 & 4.23 & 4.35 & 5.53 & 5.77 \\
\hline & 1000 & 30.33 & 34.54 & 39.49 & 47.71 & & 400 & 5.27 & 5.43 & 6.24 & 6.86 \\
\hline \multirow{6}{*}{$30 \%(\mathrm{v} / \mathrm{v}) \mathrm{DHP}$} & 0 & 3.76 & 3.89 & 4.10 & 4.49 & & 500 & 5.97 & 6.17 & 6.93 & 8.67 \\
\hline & 100 & 6.13 & 6.27 & 6.48 & 8.17 & & 600 & 6.21 & 6.62 & 8.15 & 11.19 \\
\hline & 200 & 8.85 & 9.85 & 12.26 & 13.63 & & 700 & 6.21 & 8.39 & 10.17 & 11.77 \\
\hline & 300 & 10.44 & 13.64 & 13.85 & 16.61 & & 800 & 7.11 & 8.53 & 10.54 & 12.35 \\
\hline & 400 & 12.68 & 16.40 & 17.05 & 19.38 & & 900 & 7.18 & 9.55 & 12.62 & 14.13 \\
\hline & 500 & 14.40 & 17.33 & 19.57 & 22.78 & & 1000 & 7.76 & 11.40 & 13.44 & 14.84 \\
\hline
\end{tabular}


Table S3. Values of the percentage of inhibition (P) for all solutions at different temperatures and different speeds of rotation

\begin{tabular}{|c|c|c|c|c|c|c|c|c|c|c|c|}
\hline & $\mathrm{rpm}$ & $298 \mathrm{~K}$ & $303 \mathrm{~K}$ & $308 \mathrm{~K}$ & $313 \mathrm{~K}$ & & $\mathrm{rpm}$ & $298 \mathrm{~K}$ & $303 \mathrm{~K}$ & $308 \mathrm{~K}$ & $313 \mathrm{~K}$ \\
\hline \multirow{11}{*}{$10 \%(\mathrm{v} / \mathrm{v}) \mathrm{DHP}$} & 0 & 34.82 & 35.89 & 38.20 & 38.18 & \multirow{11}{*}{$40 \%(\mathrm{v} / \mathrm{v}) \mathrm{DHP}$} & 0 & 73.62 & 75.99 & 76.16 & 75.87 \\
\hline & 100 & 46.34 & 54.04 & 57.31 & 54.11 & & 100 & 78.98 & 77.90 & 79.88 & 80.08 \\
\hline & 200 & 38.29 & 49.29 & 47.70 & 58.73 & & 200 & 72.00 & 78.62 & 75.19 & 80.53 \\
\hline & 300 & 47.91 & 51.72 & 55.04 & 58.11 & & 300 & 75.98 & 79.37 & 80.52 & 81.10 \\
\hline & 400 & 46.12 & 49.59 & 52.09 & 53.71 & & 400 & 73.90 & 77.08 & 79.01 & 80.43 \\
\hline & 500 & 47.75 & 49.14 & 46.62 & 53.75 & & 500 & 75.80 & 78.99 & 77.67 & 79.71 \\
\hline & 600 & 47.24 & 53.16 & 53.25 & 56.51 & & 600 & 77.34 & 80.07 & 80.09 & 81.18 \\
\hline & 700 & 47.36 & 50.00 & 56.80 & 57.78 & & 700 & 76.27 & 78.58 & 81.93 & 81.10 \\
\hline & 800 & 50.59 & 51.09 & 53.94 & 56.67 & & 800 & 77.83 & 79.51 & 79.09 & 79.86 \\
\hline & 900 & 49.80 & 50.88 & 56.29 & 56.16 & & 900 & 77.37 & 79.22 & 79.60 & 79.61 \\
\hline & 1000 & 48.81 & 52.20 & 54.48 & 55.99 & & 1000 & 77.87 & 80.50 & 79.02 & 79.61 \\
\hline \multirow[t]{11}{*}{$20 \%(\mathrm{v} / \mathrm{v}) \mathrm{DHP}$} & 0 & 50.34 & 52.94 & 51.10 & 52.93 & \multirow[t]{11}{*}{$50 \%(\mathrm{v} / \mathrm{v})$ DHP } & 0 & 83.01 & 84.10 & 84.35 & 83.53 \\
\hline & 100 & 56.10 & 65.80 & 67.13 & 67.34 & & 100 & 80.11 & 83.97 & 84.08 & 83.01 \\
\hline & 200 & 45.13 & 59.58 & 57.72 & 68.92 & & 200 & 78.48 & 84.60 & 79.72 & 84.56 \\
\hline & 300 & 57.32 & 63.79 & 66.44 & 68.30 & & 300 & 81.25 & 83.14 & 82.67 & 84.59 \\
\hline & 400 & 55.30 & 64.01 & 64.18 & 66.29 & & 400 & 82.52 & 84.94 & 82.96 & 84.45 \\
\hline & 500 & 56.30 & 60.02 & 58.95 & 65.12 & & 500 & 83.09 & 85.61 & 83.70 & 85.94 \\
\hline & 600 & 56.07 & 63.60 & 63.87 & 67.54 & & 600 & 84.13 & 86.36 & 84.78 & 85.01 \\
\hline & 700 & 57.00 & 59.89 & 66.86 & 66.43 & & 700 & 84.82 & 85.42 & 85.87 & 84.35 \\
\hline & 800 & 58.46 & 63.20 & 65.05 & 65.86 & & 800 & 84.64 & 85.98 & 84.43 & 83.07 \\
\hline & 900 & 59.96 & 62.37 & 66.18 & 62.29 & & 900 & 85.21 & 85.52 & 85.22 & 83.34 \\
\hline & 1000 & 59.17 & 64.15 & 64.98 & 64.86 & & 1000 & 84.71 & 86.03 & 85.40 & 82.41 \\
\hline \multirow[t]{11}{*}{$30 \%(\mathrm{v} / \mathrm{v}) \mathrm{DHP}$} & 0 & 61.27 & 63.96 & 65.14 & 65.30 & \multirow[t]{11}{*}{$60 \%(\mathrm{v} / \mathrm{v}) \mathrm{DHP}$} & 0 & 87.34 & 88.63 & 88.95 & 89.18 \\
\hline & 100 & 66.87 & 75.89 & 78.99 & 75.83 & & 100 & 87.32 & 90.16 & 90.98 & 91.72 \\
\hline & 200 & 65.16 & 72.43 & 66.87 & 74.76 & & 200 & 86.44 & 89.78 & 89.95 & 92.91 \\
\hline & 300 & 70.91 & 70.03 & 75.00 & 75.12 & & 300 & 88.21 & 90.44 & 90.02 & 91.36 \\
\hline & 400 & 69.74 & 69.36 & 72.33 & 73.98 & & 400 & 87.42 & 89.86 & 89.87 & 90.79 \\
\hline & 500 & 70.32 & 71.54 & 69.74 & 73.03 & & 500 & 87.69 & 89.86 & 89.29 & 89.74 \\
\hline & 600 & 69.51 & 73.42 & 72.52 & 73.35 & & 600 & 88.53 & 90.80 & 89.88 & 88.74 \\
\hline & 700 & 68.74 & 71.47 & 75.21 & 74.92 & & 700 & 89.41 & 88.62 & 89.47 & 89.30 \\
\hline & 800 & 70.63 & 71.81 & 73.20 & 74.08 & & 800 & 89.21 & 89.72 & 89.25 & 89.56 \\
\hline & 900 & 70.77 & 72.44 & 75.11 & 73.98 & & 900 & 89.89 & 89.13 & 88.64 & 88.76 \\
\hline & 1000 & 70.27 & 72.65 & 73.91 & 74.53 & & 1000 & 89.55 & 88.17 & 88.08 & 89.07 \\
\hline
\end{tabular}

Table S4. Values of the equilibrium constant of adsorption $\left(\mathrm{K}_{\mathrm{e}}\right)$ of DHP on copper at different temperatures and different speeds of rotation

\begin{tabular}{lcccc}
\hline rpm & $298 \mathrm{~K}$ & $303 \mathrm{~K}$ & $308 \mathrm{~K}$ & $313 \mathrm{~K}$ \\
\hline 0 & 0.27 & 0.29 & 0.30 & 0.31 \\
100 & 0.49 & 0.73 & 0.84 & 0.72 \\
200 & 0.31 & 0.54 & 0.50 & 0.81 \\
300 & 0.53 & 0.61 & 0.77 & 0.83 \\
400 & 0.48 & 0.57 & 0.65 & 0.69 \\
500 & 0.51 & 0.52 & 0.49 & 0.68 \\
600 & 0.48 & 0.63 & 0.66 & 0.83 \\
700 & 0.47 & 0.56 & 0.81 & 0.85 \\
800 & 0.55 & 0.60 & 0.71 & 0.81 \\
900 & 0.54 & 0.60 & 0.81 & 0.76 \\
1000 & 0.52 & 0.66 & 0.75 & 0.80 \\
\hline
\end{tabular}


Table S5. Values of free energy of adsorption $\left(\Delta \mathrm{G}_{\text {ads }}\right)$ for DHP on copper at different temperatures and different speeds of rotation

\begin{tabular}{|c|c|c|c|c|c|c|c|c|c|c|c|}
\hline \multirow[t]{2}{*}{ Solution } & \multirow[t]{2}{*}{$\mathrm{rpm}$} & \multicolumn{3}{|c|}{$-\Delta \mathrm{G}_{\mathrm{ads}}\left(\mathrm{kJ} \mathrm{mol}^{-1}\right)$} & \multirow[b]{2}{*}{$313 \mathrm{~K}$} & \multirow[t]{2}{*}{ Solution } & \multirow[t]{2}{*}{$\mathrm{rpm}$} & \multicolumn{3}{|c|}{$-\Delta \mathrm{G}_{\mathrm{ads}}\left(\mathrm{kJ} \mathrm{mol}^{-1}\right)$} & \multirow[b]{2}{*}{$313 \mathrm{~K}$} \\
\hline & & $298 \mathrm{~K}$ & $303 \mathrm{~K}$ & $308 \mathrm{~K}$ & & & & $298 \mathrm{~K}$ & $303 \mathrm{~K}$ & $308 \mathrm{~K}$ & \\
\hline Blank, $0 \%$ (v/v) DHP & 0 & 9.20 & 9.47 & 9.88 & 10.04 & $40 \%(\mathrm{v} / \mathrm{v}) \mathrm{DHP}$ & & 17.23 & 17.93 & 18.23 & 18.71 \\
\hline $10 \%(\mathrm{v} / \mathrm{v})$ DHP & & 12.51 & 12.98 & 13.00 & 13.41 & $50 \%(\mathrm{v} / \mathrm{v})$ DHP & & 18.88 & 19.64 & 19.64 & 20.00 \\
\hline $20 \%(\mathrm{v} / \mathrm{v}) \mathrm{DHP}$ & & 14.61 & 15.15 & 15.53 & 15.80 & $60 \%(\mathrm{v} / \mathrm{v}) \mathrm{DHP}$ & & 20.26 & 21.22 & 21.30 & 21.33 \\
\hline $30 \%(\mathrm{v} / \mathrm{v}) \mathrm{DHP}$ & & 16.73 & 17.33 & 17.64 & 17.89 & Blank, $0 \%(\mathrm{v} / \mathrm{v})$ DHP & 600 & 10.49 & 10.94 & 11.82 & 12.11 \\
\hline $40 \%(\mathrm{v} / \mathrm{v}) \mathrm{DHP}$ & & 18.67 & 19.19 & 19.55 & 19.71 & $10 \%(\mathrm{v} / \mathrm{v}) \mathrm{DHP}$ & & 13.17 & 13.69 & 14.69 & 14.88 \\
\hline $50 \%(\mathrm{v} / \mathrm{v}) \mathrm{DHP}$ & & 19.98 & 20.62 & 21.05 & 21.45 & $20 \%(\mathrm{v} / \mathrm{v}) \mathrm{DHP}$ & & 15.43 & 16.02 & 16.77 & 17.00 \\
\hline $60 \%(\mathrm{v} / \mathrm{v}) \mathrm{DHP}$ & & 10.39 & 11.34 & 11.87 & 11.73 & $30 \%(\mathrm{v} / \mathrm{v}) \mathrm{DHP}$ & & 17.08 & 17.70 & 18.54 & 18.70 \\
\hline Blank, $0 \%$ (v/v) DHP & 100 & 13.08 & 14.33 & 14.72 & 14.98 & $40 \%(\mathrm{v} / \mathrm{v}) \mathrm{DHP}$ & & 19.01 & 19.44 & 19.86 & 19.87 \\
\hline $10 \%(\mathrm{v} / \mathrm{v}) \mathrm{DHP}$ & & 15.22 & 16.59 & 17.32 & 17.13 & $50 \%(\mathrm{v} / \mathrm{v}) \mathrm{DHP}$ & & 20.48 & 20.62 & 21.18 & 21.48 \\
\hline $20 \%(\mathrm{v} / \mathrm{v}) \mathrm{DHP}$ & & 17.47 & 17.60 & 18.20 & 18.53 & $60 \%(\mathrm{v} / \mathrm{v})$ DHP & & 10.81 & 11.05 & 11.52 & 12.00 \\
\hline $30 \%(\mathrm{v} / \mathrm{v}) \mathrm{DHP}$ & & 18.20 & 19.16 & 19.50 & 19.61 & Blank, $0 \%(\mathrm{v} / \mathrm{v})$ DHP & 700 & 13.32 & 14.04 & 14.48 & 14.81 \\
\hline $40 \%(\mathrm{v} / \mathrm{v}) \mathrm{DHP}$ & & 19.98 & 21.03 & 21.62 & 22.22 & $10 \%(\mathrm{v} / \mathrm{v}) \mathrm{DHP}$ & & 15.65 & 16.06 & 16.50 & 16.89 \\
\hline $50 \%(\mathrm{v} / \mathrm{v}) \mathrm{DHP}$ & & 9.57 & 10.86 & 10.88 & 12.22 & $20 \%(\mathrm{v} / \mathrm{v}) \mathrm{DHP}$ & & 17.30 & 17.84 & 18.07 & 18.49 \\
\hline $60 \%(\mathrm{v} / \mathrm{v}) \mathrm{DHP}$ & & 11.99 & 13.66 & 13.69 & 15.17 & $30 \%(\mathrm{v} / \mathrm{v}) \mathrm{DHP}$ & & 18.97 & 19.56 & 19.57 & 19.62 \\
\hline Blank, $0 \%$ (v/v) DHP & 200 & 15.03 & 16.14 & 15.73 & 16.98 & $40 \%(\mathrm{v} / \mathrm{v}) \mathrm{DHP}$ & & 20.43 & 20.91 & 21.12 & 21.55 \\
\hline $10 \%(\mathrm{v} / \mathrm{v}) \mathrm{DHP}$ & & 16.53 & 17.71 & 17.51 & 18.60 & $50 \%(\mathrm{v} / \mathrm{v}) \mathrm{DHP}$ & & 10.74 & 11.02 & 11.76 & 11.94 \\
\hline $20 \%(\mathrm{v} / \mathrm{v}) \mathrm{DHP}$ & & 17.95 & 19.28 & 18.74 & 19.91 & $60 \%(\mathrm{v} / \mathrm{v}) \mathrm{DHP}$ & & 13.47 & 13.95 & 14.61 & 14.41 \\
\hline $30 \%(\mathrm{v} / \mathrm{v}) \mathrm{DHP}$ & & 19.78 & 20.92 & 21.32 & 22.66 & Blank, $0 \%(\mathrm{v} / \mathrm{v})$ DHP & 800 & 15.67 & 16.14 & 16.76 & 16.87 \\
\hline $40 \%(\mathrm{v} / \mathrm{v}) \mathrm{DHP}$ & & 10.55 & 11.11 & 11.64 & 12.15 & $10 \%(\mathrm{v} / \mathrm{v}) \mathrm{DHP}$ & & 17.24 & 17.80 & 18.15 & 18.45 \\
\hline $50 \%(\mathrm{v} / \mathrm{v}) \mathrm{DHP}$ & & 13.20 & 14.11 & 14.64 & 15.10 & $20 \%(\mathrm{v} / \mathrm{v}) \mathrm{DHP}$ & & 19.08 & 19.47 & 19.73 & 19.67 \\
\hline $60 \%(\mathrm{v} / \mathrm{v}) \mathrm{DHP}$ & & 15.69 & 15.84 & 16.74 & 17.03 & $30 \%(\mathrm{v} / \mathrm{v}) \mathrm{DHP}$ & & 20.61 & 20.75 & 20.97 & 21.34 \\
\hline Blank, $0 \%$ (v/v) DHP & 300 & 17.04 & 17.82 & 18.30 & 18.70 & $40 \%(\mathrm{v} / \mathrm{v}) \mathrm{DHP}$ & & 10.64 & 11.16 & 11.58 & 11.92 \\
\hline $10 \%(\mathrm{v} / \mathrm{v}) \mathrm{DHP}$ & & 18.38 & 19.01 & 19.24 & 19.92 & $50 \%(\mathrm{v} / \mathrm{v}) \mathrm{DHP}$ & & 13.39 & 14.15 & 14.47 & 14.70 \\
\hline $20 \%(\mathrm{v} / \mathrm{v}) \mathrm{DHP}$ & & 20.18 & 21.11 & 21.34 & 22.10 & $60 \%(\mathrm{v} / \mathrm{v}) \mathrm{DHP}$ & & 15.61 & 16.16 & 16.60 & 16.95 \\
\hline $30 \%(\mathrm{v} / \mathrm{v}) \mathrm{DHP}$ & & 10.37 & 10.90 & 11.33 & 11.68 & Blank, $0 \%(\mathrm{v} / \mathrm{v})$ DHP & 900 & 17.31 & 18.00 & 18.06 & 18.45 \\
\hline $40 \%(\mathrm{v} / \mathrm{v}) \mathrm{DHP}$ & & 13.00 & 14.13 & 14.39 & 14.86 & $10 \%(\mathrm{v} / \mathrm{v})$ DHP & & 18.99 & 19.57 & 19.76 & 19.50 \\
\hline $50 \%(\mathrm{v} / \mathrm{v}) \mathrm{DHP}$ & & 15.55 & 15.76 & 16.39 & 16.88 & $20 \%(\mathrm{v} / \mathrm{v}) \mathrm{DHP}$ & & 20.52 & 20.51 & 20.83 & 21.42 \\
\hline $60 \%(\mathrm{v} / \mathrm{v}) \mathrm{DHP}$ & & 16.77 & 17.48 & 18.06 & 18.58 & $30 \%(\mathrm{v} / \mathrm{v}) \mathrm{DHP}$ & & 9.20 & 9.47 & 9.88 & 10.04 \\
\hline Blank, $0 \%(\mathrm{v} / \mathrm{v})$ DHP & 400 & 18.59 & 19.35 & 19.29 & 19.89 & $40 \%(\mathrm{v} / \mathrm{v}) \mathrm{DHP}$ & & 12.51 & 12.98 & 13.00 & 13.41 \\
\hline $10 \%(\mathrm{v} / \mathrm{v}) \mathrm{DHP}$ & & 20.00 & 20.95 & 21.29 & 21.92 & $50 \%(\mathrm{v} / \mathrm{v}) \mathrm{DHP}$ & & 14.61 & 15.15 & 15.53 & 15.80 \\
\hline $20 \%(\mathrm{v} / \mathrm{v}) \mathrm{DHP}$ & & 10.53 & 10.85 & 10.77 & 11.69 & $60 \%(\mathrm{v} / \mathrm{v}) \mathrm{DHP}$ & & 16.73 & 17.33 & 17.64 & 17.89 \\
\hline $30 \%(\mathrm{v} / \mathrm{v}) \mathrm{DHP}$ & & 13.10 & 13.71 & 13.82 & 14.73 & Blank, $0 \%(\mathrm{v} / \mathrm{v})$ DHP & 1000 & 18.67 & 19.19 & 19.55 & 19.71 \\
\hline $40 \%(\mathrm{v} / \mathrm{v}) \mathrm{DHP}$ & & 15.61 & 16.03 & 16.07 & 16.75 & $10 \%(\mathrm{v} / \mathrm{v}) \mathrm{DHP}$ & & 19.98 & 20.62 & 21.05 & 21.45 \\
\hline $50 \%(\mathrm{v} / \mathrm{v}) \mathrm{DHP}$ & & 17.02 & 17.76 & 17.86 & 18.47 & $20 \%(\mathrm{v} / \mathrm{v}) \mathrm{DHP}$ & & 10.39 & 11.34 & 11.87 & 11.73 \\
\hline $60 \%(\mathrm{v} / \mathrm{v}) \mathrm{DHP}$ & & 18.69 & 19.48 & 19.43 & 20.20 & $30 \%(\mathrm{v} / \mathrm{v}) \mathrm{DHP}$ & & 13.08 & 14.33 & 14.72 & 14.98 \\
\hline Blank, $0 \%$ (v/v) DHP & 500 & 20.06 & 20.95 & 21.14 & 21.60 & $40 \%(\mathrm{v} / \mathrm{v}) \mathrm{DHP}$ & & 15.22 & 16.59 & 17.32 & 17.13 \\
\hline $10 \%(\mathrm{v} / \mathrm{v}) \mathrm{DHP}$ & & 10.48 & 11.26 & 11.45 & 11.98 & $50 \%(\mathrm{v} / \mathrm{v}) \mathrm{DHP}$ & & 17.47 & 17.60 & 18.20 & 18.53 \\
\hline $20 \%(\mathrm{v} / \mathrm{v}) \mathrm{DHP}$ & & 13.08 & 14.09 & 14.35 & 15.01 & $60 \%(\mathrm{v} / \mathrm{v}) \mathrm{DHP}$ & & 18.20 & 19.16 & 19.50 & 19.61 \\
\hline $30 \%(\mathrm{v} / \mathrm{v}) \mathrm{DHP}$ & & 15.52 & 16.26 & 16.42 & 16.79 & & & & & & \\
\hline
\end{tabular}


Table S6. Electrodeposition average thermodynamic parameters within the temperature range $298-313 \mathrm{~K}$ for DHP solutions at different speeds of rotation

\begin{tabular}{|c|c|c|c|c|c|}
\hline & $\mathrm{rpm}$ & $\mathrm{E}_{\mathrm{a}}\left(\mathrm{kJ} \mathrm{mol}^{-1}\right)$ & $\Delta \mathrm{H}^{*}\left(\mathrm{~kJ} \mathrm{~mol}^{-1}\right)$ & $\Delta \mathrm{S}^{*}\left(\mathrm{~J} \mathrm{~mol}^{-1} \mathrm{~K}^{-1}\right)$ & $\Delta \mathrm{G}^{*}\left(\mathrm{~J} \mathrm{~mol}^{-1} \mathrm{~K}^{-1}\right)$ \\
\hline Blank, 0\% (v/v) DHP & 0 & 14.7 & 12.2 & -185.1 & 68.7 \\
\hline $10 \%(\mathrm{v} / \mathrm{v}) \mathrm{DHP}$ & & 11.7 & 9.0 & -198.9 & 69.9 \\
\hline $20 \%(\mathrm{v} / \mathrm{v}) \mathrm{DHP}$ & & 12.8 & 8.9 & -197.5 & 70.6 \\
\hline $30 \%(\mathrm{v} / \mathrm{v}) \mathrm{DHP}$ & & 9.1 & 7.3 & -212.2 & 71.3 \\
\hline $40 \%(\mathrm{v} / \mathrm{v}) \mathrm{DHP}$ & & 10.4 & 8.6 & -211.0 & 72.3 \\
\hline $50 \%(\mathrm{v} / \mathrm{v}) \mathrm{DHP}$ & & 13.0 & 8.6 & -206.0 & 73.4 \\
\hline $60 \%(\mathrm{v} / \mathrm{v}) \mathrm{DHP}$ & & 6.9 & 6.9 & -228.6 & 74.2 \\
\hline Blank, 0\% (v/v) DHP & 100 & 27.9 & 25.4 & -134.7 & 66.5 \\
\hline $10 \%(\mathrm{v} / \mathrm{v}) \mathrm{DHP}$ & & 22.2 & 18.5 & -159.7 & 68.5 \\
\hline $20 \%(\mathrm{v} / \mathrm{v}) \mathrm{DHP}$ & & 16.3 & 25.4 & -181.5 & 69.2 \\
\hline $30 \%(\mathrm{v} / \mathrm{v}) \mathrm{DHP}$ & & 13.7 & 13.3 & -192.6 & 70.0 \\
\hline $40 \%(\mathrm{v} / \mathrm{v}) \mathrm{DHP}$ & & 26.8 & 14.8 & -151.4 & 70.5 \\
\hline $50 \%(\mathrm{v} / \mathrm{v}) \mathrm{DHP}$ & & 23.2 & 12.6 & -164.9 & 71.0 \\
\hline $60 \%(\mathrm{v} / \mathrm{v}) \mathrm{DHP}$ & & 9.5 & 2.8 & -214.3 & 72.4 \\
\hline Blank, 0\% (v/v) DHP & 200 & 31.8 & 29.3 & -119.1 & 65.7 \\
\hline $10 \%(\mathrm{v} / \mathrm{v}) \mathrm{DHP}$ & & 17.4 & 16.5 & -172.2 & 67.4 \\
\hline $20 \%(\mathrm{v} / \mathrm{v}) \mathrm{DHP}$ & & 9.9 & 19.6 & -198.6 & 68.0 \\
\hline $30 \%(\mathrm{v} / \mathrm{v})$ DHP & & 23.5 & 17.6 & -156.6 & 68.8 \\
\hline $40 \%(\mathrm{v} / \mathrm{v}) \mathrm{DHP}$ & & 21.0 & 14.3 & -166.9 & 69.4 \\
\hline $50 \%(\mathrm{v} / \mathrm{v}) \mathrm{DHP}$ & & 24.4 & 20.0 & -157.9 & 70.1 \\
\hline $60 \%(\mathrm{v} / \mathrm{v}) \mathrm{DHP}$ & & 5.2 & 14.9 & -225.7 & 71.6 \\
\hline Blank, 0\% (v/v) DHP & 300 & 32.0 & 29.4 & -116.3 & 65.0 \\
\hline $10 \%(v / v)$ DHP & & 20.7 & 16.1 & -159.5 & 66.9 \\
\hline $20 \%(\mathrm{v} / \mathrm{v}) \mathrm{DHP}$ & & 16.9 & 20.0 & -174.2 & 67.6 \\
\hline $30 \%(\mathrm{v} / \mathrm{v}) \mathrm{DHP}$ & & 21.9 & 18.1 & -160.1 & 68.3 \\
\hline $40 \%(\mathrm{v} / \mathrm{v}) \mathrm{DHP}$ & & 19.8 & 15.5 & -169.1 & 69.0 \\
\hline $50 \%(\mathrm{v} / \mathrm{v}) \mathrm{DHP}$ & & 23.3 & 15.6 & -159.5 & 69.5 \\
\hline $60 \%(\mathrm{v} / \mathrm{v}) \mathrm{DHP}$ & & 18.1 & 12.6 & -180.9 & 70.8 \\
\hline Blank, 0\% (v/v) DHP & 400 & 29.0 & 26.5 & -124.9 & 64.6 \\
\hline $10 \%(v / v)$ DHP & & 21.1 & 15.9 & -156.5 & 66.4 \\
\hline $20 \%(\mathrm{v} / \mathrm{v})$ DHP & & 15.7 & 22.3 & -176.6 & 67.1 \\
\hline $30 \%(\mathrm{v} / \mathrm{v}) \mathrm{DHP}$ & & 20.4 & 18.3 & -163.4 & 67.8 \\
\hline $40 \%(\mathrm{v} / \mathrm{v}) \mathrm{DHP}$ & & 14.2 & 14.5 & -185.8 & 68.4 \\
\hline $50 \%(\mathrm{v} / \mathrm{v}) \mathrm{DHP}$ & & 25.4 & 14.6 & -151.7 & 69.2 \\
\hline $60 \%(\mathrm{v} / \mathrm{v}) \mathrm{DHP}$ & & 14.4 & 19.3 & -191.5 & 70.4 \\
\hline Blank, 0\% (v/v) DHP & 500 & 26.7 & 24.2 & -131.5 & 64.3 \\
\hline $10 \%(\mathrm{v} / \mathrm{v}) \mathrm{DHP}$ & & 21.8 & 16.4 & -153.1 & 66.1 \\
\hline $20 \%(\mathrm{v} / \mathrm{v}) \mathrm{DHP}$ & & 16.7 & 21.9 & -172.0 & 66.7 \\
\hline $30 \%(\mathrm{v} / \mathrm{v}) \mathrm{DHP}$ & & 23.2 & 17.8 & -153.2 & 67.5 \\
\hline $40 \%(\mathrm{v} / \mathrm{v}) \mathrm{DHP}$ & & 19.4 & 18.6 & -167.9 & 68.2 \\
\hline $50 \%(\mathrm{v} / \mathrm{v}) \mathrm{DHP}$ & & 20.1 & 23.2 & -168.8 & 69.1 \\
\hline $60 \%(\mathrm{v} / \mathrm{v}) \mathrm{DHP}$ & & 19.0 & 18.4 & -175.1 & 70.0 \\
\hline Blank, 0\% (v/v) DHP & 600 & 30.1 & 27.6 & -119.0 & 63.9 \\
\hline $10 \%(\mathrm{v} / \mathrm{v}) \mathrm{DHP}$ & & 21.0 & 16.1 & -154.9 & 65.8 \\
\hline $20 \%(\mathrm{v} / \mathrm{v}) \mathrm{DHP}$ & & 15.9 & 19.1 & -173.9 & 66.4 \\
\hline $30 \%(\mathrm{v} / \mathrm{v}) \mathrm{DHP}$ & & 24.3 & 18.6 & -148.7 & 67.2 \\
\hline $40 \%(\mathrm{v} / \mathrm{v}) \mathrm{DHP}$ & & 21.4 & 18.4 & -160.7 & 68.0 \\
\hline $50 \%(\mathrm{v} / \mathrm{v}) \mathrm{DHP}$ & & 29.1 & 27.2 & -138.1 & 68.7 \\
\hline $60 \%(\mathrm{v} / \mathrm{v}) \mathrm{DHP}$ & & 30.5 & 21.6 & -136.4 & 69.6 \\
\hline Blank, 0\% (v/v) DHP & 700 & 33.5 & 30.9 & -107.1 & 63.7 \\
\hline $10 \%(\mathrm{v} / \mathrm{v}) \mathrm{DHP}$ & & 20.9 & 16.9 & -154.5 & 65.6 \\
\hline $20 \%(\mathrm{v} / \mathrm{v}) \mathrm{DHP}$ & & 19.0 & 24.9 & -162.9 & 66.2 \\
\hline $30 \%(\mathrm{v} / \mathrm{v}) \mathrm{DHP}$ & & 21.0 & 17.6 & -158.7 & 67.0 \\
\hline $40 \%(\mathrm{v} / \mathrm{v}) \mathrm{DHP}$ & & 20.2 & 16.2 & -163.9 & 67.7 \\
\hline $50 \%(\mathrm{v} / \mathrm{v}) \mathrm{DHP}$ & & 34.3 & 25.0 & -120.1 & 68.5 \\
\hline $60 \%(\mathrm{v} / \mathrm{v}) \mathrm{DHP}$ & & 32.8 & 26.7 & -127.8 & 69.3 \\
\hline Blank, 0\% (v/v) DHP & 800 & 29.8 & 27.3 & -118.4 & 63.5 \\
\hline $10 \%(\mathrm{v} / \mathrm{v}) \mathrm{DHP}$ & & 22.8 & 19.4 & -147.7 & 65.4 \\
\hline $20 \%(\mathrm{v} / \mathrm{v}) \mathrm{DHP}$ & & 19.8 & 22.4 & -159.4 & 66.0 \\
\hline $30 \%(\mathrm{v} / \mathrm{v}) \mathrm{DHP}$ & & 23.2 & 17.0 & -150.8 & 66.7 \\
\hline $40 \%(\mathrm{v} / \mathrm{v}) \mathrm{DHP}$ & & 25.7 & 17.9 & -145.1 & 67.4 \\
\hline $50 \%(\mathrm{v} / \mathrm{v}) \mathrm{DHP}$ & & 35.9 & 24.9 & -114.2 & 68.2 \\
\hline $60 \%(\mathrm{v} / \mathrm{v}) \mathrm{DHP}$ & & 29.0 & 24.2 & -139.9 & 69.2 \\
\hline
\end{tabular}


Table S6. cont.

\begin{tabular}{|c|c|c|c|c|c|}
\hline & $\mathrm{rpm}$ & $\mathrm{E}_{\mathrm{a}}\left(\mathrm{kJ} \mathrm{mol}^{-1}\right)$ & $\Delta \mathrm{H}^{*}\left(\mathrm{~kJ} \mathrm{~mol}^{-1}\right)$ & $\Delta \mathrm{S}^{*}\left(\mathrm{~J} \mathrm{~mol}^{-1} \mathrm{~K}^{-1}\right)$ & $\Delta \mathrm{G}^{*}\left(\mathrm{~J} \mathrm{~mol}^{-1} \mathrm{~K}^{-1}\right)$ \\
\hline Blank, 0\% (v/v) DHP & 900 & 30.2 & 27.7 & -116.6 & 63.3 \\
\hline $10 \%(\mathrm{v} / \mathrm{v}) \mathrm{DHP}$ & & 22.1 & 21.2 & -149.5 & 65.2 \\
\hline $20 \%$ (v/v) DHP & & 25.7 & 28.7 & -139.6 & 65.8 \\
\hline $30 \%(\mathrm{v} / \mathrm{v}) \mathrm{DHP}$ & & 23.2 & 19.5 & -150.5 & 66.6 \\
\hline $40 \%(\mathrm{v} / \mathrm{v}) \mathrm{DHP}$ & & 25.0 & 21.5 & -146.5 & 67.2 \\
\hline $50 \%(\mathrm{v} / \mathrm{v}) \mathrm{DHP}$ & & 36.0 & 24.9 & -113.3 & 68.1 \\
\hline $60 \%(\mathrm{v} / \mathrm{v}) \mathrm{DHP}$ & & 35.9 & 25.4 & -116.4 & 68.9 \\
\hline Blank, 0\% (v/v) DHP & 1000 & 30.5 & 28.0 & -114.9 & 63.1 \\
\hline $10 \%(\mathrm{v} / \mathrm{v}) \mathrm{DHP}$ & & 22.7 & 17.6 & -146.7 & 65.0 \\
\hline $20 \%(\mathrm{v} / \mathrm{v}) \mathrm{DHP}$ & & 23.1 & 29.2 & -147.6 & 65.7 \\
\hline $30 \%(\mathrm{v} / \mathrm{v}) \mathrm{DHP}$ & & 22.6 & 17.6 & -151.8 & 66.4 \\
\hline $40 \%(\mathrm{v} / \mathrm{v}) \mathrm{DHP}$ & & 27.8 & 20.6 & -136.9 & 67.1 \\
\hline $50 \%(\mathrm{v} / \mathrm{v}) \mathrm{DHP}$ & & 37.6 & 22.2 & -107.3 & 67.9 \\
\hline $60 \%(\mathrm{v} / \mathrm{v}) \mathrm{DHP}$ & & 32.9 & 24.0 & -125.5 & 68.7 \\
\hline
\end{tabular}

Table S7. Values of diffusion coefficient (D) for all mixtures at different temperatures

\begin{tabular}{|c|c|c|c|c|c|}
\hline & $\mathrm{rpm}$ & $\begin{array}{c}298 \mathrm{~K} \\
\mathrm{D} /\left(\mathrm{cm}^{2} \mathrm{~s}^{-1} \times 10^{-5}\right)\end{array}$ & $\begin{array}{c}303 \mathrm{~K} \\
\mathrm{D} /\left(\mathrm{cm}^{2} \mathrm{~s}^{-1} \times 10^{-5}\right)\end{array}$ & $\begin{array}{c}308 \mathrm{~K} \\
\mathrm{D} /\left(\mathrm{cm}^{2} \mathrm{~s}^{-1} \times 10^{-5}\right)\end{array}$ & $\begin{array}{c}313 \mathrm{~K} \\
\mathrm{D} /\left(\mathrm{cm}^{2} \mathrm{~s}^{-1} \times 10^{-5}\right)\end{array}$ \\
\hline \multirow{10}{*}{ Blank, 0\% (v/v) DHP } & 100 & 1.280 & 1.866 & 2.305 & 2.530 \\
\hline & 200 & 1.016 & 1.439 & 1.441 & 2.468 \\
\hline & 300 & 0.987 & 1.348 & 1.735 & 2.208 \\
\hline & 400 & 0.918 & 1.268 & 1.497 & 1.914 \\
\hline & 500 & 0.904 & 1.216 & 1.266 & 1.825 \\
\hline & 600 & 0.879 & 1.291 & 1.463 & 1.928 \\
\hline & 700 & 0.842 & 1.136 & 1.637 & 1.908 \\
\hline & 800 & 0.873 & 1.179 & 1.450 & 1.848 \\
\hline & 900 & 0.864 & 1.134 & 1.550 & 1.785 \\
\hline & 1000 & 0.825 & 1.167 & 1.413 & 1.796 \\
\hline \multirow[t]{10}{*}{$10 \%(\mathrm{v} / \mathrm{v}) \mathrm{DHP}$} & 100 & 0.451 & 0.568 & 0.626 & 0.769 \\
\hline & 200 & 0.432 & 0.510 & 0.537 & 0.636 \\
\hline & 300 & 0.365 & 0.443 & 0.511 & 0.582 \\
\hline & 400 & 0.358 & 0.446 & 0.486 & 0.590 \\
\hline & 500 & 0.336 & 0.433 & 0.487 & 0.561 \\
\hline & 600 & 0.332 & 0.405 & 0.457 & 0.539 \\
\hline & 700 & 0.317 & 0.395 & 0.453 & 0.509 \\
\hline & 800 & 0.298 & 0.396 & 0.443 & 0.514 \\
\hline & 900 & 0.302 & 0.383 & 0.437 & 0.505 \\
\hline & 1000 & 0.297 & 0.378 & 0.424 & 0.512 \\
\hline \multirow[t]{10}{*}{$20 \%$ (v/v) DHP } & 100 & 0.355 & 0.386 & 0.449 & 0.488 \\
\hline & 200 & 0.387 & 0.386 & 0.415 & 0.440 \\
\hline & 300 & 0.288 & 0.305 & 0.349 & 0.406 \\
\hline & 400 & 0.288 & 0.284 & 0.333 & 0.387 \\
\hline & 500 & 0.274 & 0.321 & 0.348 & 0.390 \\
\hline & 600 & 0.268 & 0.295 & 0.330 & 0.368 \\
\hline & 700 & 0.249 & 0.301 & 0.323 & 0.384 \\
\hline & 800 & 0.245 & 0.273 & 0.310 & 0.382 \\
\hline & 900 & 0.228 & 0.272 & 0.315 & 0.430 \\
\hline & 1000 & 0.225 & 0.260 & 0.304 & 0.388 \\
\hline \multirow[t]{10}{*}{$30 \%$ (v/v) DHP } & 100 & 0.249 & 0.244 & 0.243 & 0.332 \\
\hline & 200 & 0.208 & 0.232 & 0.309 & 0.347 \\
\hline & 300 & 0.173 & 0.247 & 0.240 & 0.303 \\
\hline & 400 & 0.171 & 0.241 & 0.243 & 0.282 \\
\hline & 500 & 0.163 & 0.206 & 0.236 & 0.284 \\
\hline & 600 & 0.166 & 0.197 & 0.234 & 0.295 \\
\hline & 700 & 0.165 & 0.193 & 0.224 & 0.265 \\
\hline & 800 & 0.155 & 0.197 & 0.224 & 0.270 \\
\hline & 900 & 0.152 & 0.183 & 0.213 & 0.263 \\
\hline & 1000 & 0.149 & 0.186 & 0.209 & 0.256 \\
\hline
\end{tabular}


Table S7. cont.

\begin{tabular}{|c|c|c|c|c|c|}
\hline & $\mathrm{rpm}$ & $\begin{array}{c}298 \mathrm{~K} \\
\mathrm{D} /\left(\mathrm{cm}^{2} \mathrm{~s}^{-1} \times 10^{-5}\right)\end{array}$ & $\begin{array}{c}303 \mathrm{~K} \\
\mathrm{D} /\left(\mathrm{cm}^{2} \mathrm{~s}^{-1} \times 10^{-5}\right)\end{array}$ & $\begin{array}{c}308 \mathrm{~K} \\
\mathrm{D} /\left(\mathrm{cm}^{2} \mathrm{~s}^{-1} \times 10^{-5}\right)\end{array}$ & $\begin{array}{c}313 \mathrm{~K} \\
\mathrm{D} /\left(\mathrm{cm}^{2} \mathrm{~s}^{-1} \times 10^{-5}\right)\end{array}$ \\
\hline \multirow[t]{10}{*}{$40 \%$ (v/v) DHP } & 100 & 0.136 & 0.236 & 0.252 & 0.272 \\
\hline & 200 & 0.164 & 0.173 & 0.218 & 0.256 \\
\hline & 300 & 0.142 & 0.153 & 0.180 & 0.219 \\
\hline & 400 & 0.150 & 0.170 & 0.175 & 0.200 \\
\hline & 500 & 0.132 & 0.142 & 0.163 & 0.202 \\
\hline & 600 & 0.116 & 0.139 & 0.157 & 0.190 \\
\hline & 700 & 0.119 & 0.137 & 0.151 & 0.189 \\
\hline & 800 & 0.111 & 0.133 & 0.168 & 0.202 \\
\hline & 900 & 0.113 & 0.130 & 0.173 & 0.199 \\
\hline & 1000 & 0.104 & 0.121 & 0.165 & 0.200 \\
\hline \multirow[t]{10}{*}{$50 \%(\mathrm{v} / \mathrm{v}) \mathrm{DHP}$} & 100 & 0.140 & 0.160 & 0.196 & 0.237 \\
\hline & 200 & 0.121 & 0.116 & 0.178 & 0.200 \\
\hline & 300 & 0.108 & 0.125 & 0.168 & 0.178 \\
\hline & 400 & 0.090 & 0.099 & 0.141 & 0.157 \\
\hline & 500 & 0.084 & 0.088 & 0.111 & 0.128 \\
\hline & 600 & 0.074 & 0.086 & 0.116 & 0.149 \\
\hline & 700 & 0.066 & 0.084 & 0.115 & 0.158 \\
\hline & 800 & 0.070 & 0.082 & 0.119 & 0.172 \\
\hline & 900 & 0.065 & 0.083 & 0.117 & 0.163 \\
\hline & 1000 & 0.066 & 0.081 & 0.105 & 0.178 \\
\hline \multirow[t]{10}{*}{$60 \%(\mathrm{v} / \mathrm{v})$ DHP } & 100 & 0.158 & 0.085 & 0.091 & 0.088 \\
\hline & 200 & 0.137 & 0.069 & 0.068 & 0.067 \\
\hline & 300 & 0.122 & 0.059 & 0.081 & 0.082 \\
\hline & 400 & 0.102 & 0.060 & 0.071 & 0.078 \\
\hline & 500 & 0.095 & 0.058 & 0.066 & 0.089 \\
\hline & 600 & 0.084 & 0.053 & 0.069 & 0.108 \\
\hline & 700 & 0.075 & 0.065 & 0.083 & 0.099 \\
\hline & 800 & 0.079 & 0.057 & 0.076 & 0.092 \\
\hline & 900 & 0.074 & 0.060 & 0.088 & 0.100 \\
\hline & 1000 & 0.074 & 0.071 & 0.087 & 0.096 \\
\hline
\end{tabular}

Table S8a. Dimensionless groups used in dimensional analysis for all solutions at 298 and $303 \mathrm{~K}$

\begin{tabular}{|c|c|c|c|c|c|c|c|}
\hline & $\mathrm{rpm}$ & $\begin{array}{c}298 \mathrm{~K} \\
S h=k l / D\end{array}$ & $S c=v / D$ & $R e=l U / \mathrm{V}$ & $\begin{array}{c}303 \mathrm{~K} \\
S h=k l / D\end{array}$ & $S c=\mathrm{v} / D$ & $R e=l U / \mathrm{N}$ \\
\hline \multirow{10}{*}{ Blank, 0\% (v/v) DHP } & 100 & 92 & 771 & 705 & 83 & 475 & 784 \\
\hline & 200 & 162 & 971 & 1409 & 148 & 616 & 1568 \\
\hline & 300 & 217 & 1000 & 2114 & 202 & 658 & 2351 \\
\hline & 400 & 272 & 1075 & 2818 & 252 & 699 & 3135 \\
\hline & 500 & 320 & 1091 & 3523 & 299 & 729 & 3919 \\
\hline & 600 & 368 & 1122 & 4228 & 332 & 687 & 4703 \\
\hline & 700 & 416 & 1172 & 4932 & 388 & 780 & 5486 \\
\hline & 800 & 451 & 1129 & 5637 & 420 & 752 & 6270 \\
\hline & 900 & 491 & 1142 & 6342 & 462 & 782 & 7054 \\
\hline & 1000 & 538 & 1196 & 7046 & 493 & 760 & 7838 \\
\hline \multirow[t]{10}{*}{$10 \%(\mathrm{v} / \mathrm{v}) \mathrm{DHP}$} & 100 & 131 & 2262 & 681 & 126 & 1614 & 757 \\
\hline & 200 & 217 & 2364 & 1362 & 212 & 1798 & 1514 \\
\hline & 300 & 306 & 2797 & 2042 & 296 & 2070 & 2272 \\
\hline & 400 & 377 & 2853 & 2723 & 361 & 2059 & 3029 \\
\hline & 500 & 450 & 3037 & 3404 & 426 & 2117 & 3786 \\
\hline & 600 & 514 & 3077 & 4085 & 496 & 2265 & 4543 \\
\hline & 700 & 582 & 3225 & 4765 & 558 & 2326 & 5301 \\
\hline & 800 & 653 & 3429 & 5446 & 612 & 2320 & 6058 \\
\hline & 900 & 706 & 3383 & 6127 & 672 & 2395 & 6815 \\
\hline & 1000 & 764 & 3437 & 6808 & 728 & 2429 & 7572 \\
\hline
\end{tabular}


Table S8a. cont.

\begin{tabular}{|c|c|c|c|c|c|c|c|}
\hline & rpm & $\begin{array}{c}298 \mathrm{~K} \\
S h=k l / D\end{array}$ & $S c=\mathrm{v} / D$ & $R e=l U / v$ & $\begin{array}{c}303 \mathrm{~K} \\
S h=k l / D\end{array}$ & $S c=\mathrm{v} / D$ & $R e=l U / \mathrm{N}$ \\
\hline \multirow[t]{10}{*}{$20 \%(\mathrm{v} / \mathrm{v}) \mathrm{DHP}$} & 100 & 137 & 3291 & 594 & 137 & 2722 & 661 \\
\hline & 200 & 215 & 3023 & 1189 & 223 & 2723 & 1322 \\
\hline & 300 & 317 & 4060 & 1783 & 323 & 3446 & 1983 \\
\hline & 400 & 388 & 4062 & 2377 & 405 & 3700 & 2644 \\
\hline & 500 & 462 & 4270 & 2971 & 453 & 3278 & 3305 \\
\hline & 600 & 529 & 4357 & 3566 & 531 & 3569 & 3966 \\
\hline & 700 & 605 & 4703 & 4160 & 586 & 3490 & 4627 \\
\hline & 800 & 668 & 4782 & 4754 & 666 & 3844 & 5288 \\
\hline & 900 & 744 & 5121 & 5348 & 725 & 3859 & 5949 \\
\hline & 1000 & 805 & 5202 & 5943 & 793 & 4045 & 6610 \\
\hline \multirow[t]{10}{*}{$30 \%$ (v/v) DHP } & 100 & 147 & 5483 & 508 & 153 & 5040 & 565 \\
\hline & 200 & 254 & 6583 & 1016 & 254 & 5306 & 1130 \\
\hline & 300 & 361 & 7922 & 1524 & 329 & 4974 & 1695 \\
\hline & 400 & 443 & 8009 & 2032 & 407 & 5111 & 2260 \\
\hline & 500 & 526 & 8375 & 2540 & 503 & 5979 & 2825 \\
\hline & 600 & 595 & 8264 & 3048 & 581 & 6256 & 3391 \\
\hline & 700 & 664 & 8302 & 3556 & 651 & 6372 & 3956 \\
\hline & 800 & 745 & 8815 & 4064 & 710 & 6254 & 4521 \\
\hline & 900 & 814 & 8981 & 4572 & 792 & 6735 & 5086 \\
\hline & 1000 & 883 & 9159 & 5080 & 847 & 6623 & 5651 \\
\hline \multirow[t]{10}{*}{$40 \%(\mathrm{v} / \mathrm{v})$ DHP } & 100 & 170 & 12139 & 420 & 145 & 6302 & 467 \\
\hline & 200 & 259 & 10099 & 840 & 264 & 8605 & 935 \\
\hline & 300 & 362 & 11645 & 1261 & 366 & 9701 & 1402 \\
\hline & 400 & 434 & 11008 & 1681 & 432 & 8763 & 1870 \\
\hline & 500 & 532 & 12563 & 2101 & 537 & 10463 & 2337 \\
\hline & 600 & 633 & 14308 & 2521 & 615 & 10690 & 2804 \\
\hline & 700 & 699 & 13912 & 2941 & 689 & 10861 & 3272 \\
\hline & 800 & 786 & 14903 & 3362 & 765 & 11217 & 3739 \\
\hline & 900 & 847 & 14593 & 3782 & 836 & 11407 & 4207 \\
\hline & 1000 & 939 & 15826 & 4202 & 923 & 12240 & 4674 \\
\hline \multirow[t]{10}{*}{$50 \%(\mathrm{v} / \mathrm{v}) \mathrm{DHP}$} & 100 & 157 & 14565 & 342 & 156 & 11415 & 380 \\
\hline & 200 & 269 & 16733 & 684 & 283 & 15767 & 761 \\
\hline & 300 & 372 & 18837 & 1026 & 366 & 14614 & 1141 \\
\hline & 400 & 486 & 22573 & 1368 & 488 & 18513 & 1521 \\
\hline & 500 & 581 & 24140 & 1710 & 593 & 20729 & 1902 \\
\hline & 600 & 691 & 27402 & 2052 & 679 & 21195 & 2282 \\
\hline & 700 & 801 & 30637 & 2394 & 764 & 21723 & 2662 \\
\hline & 800 & 862 & 28991 & 2736 & 845 & 22242 & 3043 \\
\hline & 900 & 960 & 31091 & 3078 & 915 & 22006 & 3423 \\
\hline & 1000 & 1032 & 30937 & 3419 & 994 & 22612 & 3804 \\
\hline \multirow[t]{10}{*}{$60 \%(\mathrm{v} / \mathrm{v}) \mathrm{DHP}$} & 100 & 139 & 16218 & 271 & 180 & 27130 & 302 \\
\hline & 200 & 238 & 18633 & 543 & 314 & 33190 & 604 \\
\hline & 300 & 329 & 20976 & 814 & 443 & 39275 & 906 \\
\hline & 400 & 429 & 25135 & 1086 & 536 & 38119 & 1208 \\
\hline & 500 & 514 & 26880 & 1357 & 637 & 39764 & 1510 \\
\hline & 600 & 611 & 30512 & 1629 & 747 & 43491 & 1812 \\
\hline & 700 & 708 & 34115 & 1900 & 774 & 35566 & 2114 \\
\hline & 800 & 762 & 32281 & 2172 & 887 & 40101 & 2416 \\
\hline & 900 & 849 & 34620 & 2443 & 947 & 38227 & 2718 \\
\hline & 1000 & 912 & 34448 & 2715 & 964 & 32599 & 3020 \\
\hline
\end{tabular}


Table S8b. Dimensionless groups used in dimensional analysis for all solutions at 308 and $313 \mathrm{~K}$

\begin{tabular}{|c|c|c|c|c|c|c|c|}
\hline$\%(\mathrm{v} / \mathrm{v}) \mathrm{DHP}$ & $\mathrm{rpm}$ & $\begin{array}{c}308 \mathrm{~K} \\
S h=k l / D\end{array}$ & $S c=v / D$ & $R e=l U / N$ & $\begin{array}{c}313 \mathrm{~K} \\
S h=k l / D\end{array}$ & $S c=\mathrm{v} / D$ & $R e=l U / \mathrm{V}$ \\
\hline \multirow[t]{10}{*}{ Blank, 0\% (v/v) DHP } & 100 & 80 & 349 & 865 & 80 & 290 & 948 \\
\hline & 200 & 153 & 557 & 1730 & 131 & 297 & 1896 \\
\hline & 300 & 191 & 463 & 2595 & 180 & 332 & 2844 \\
\hline & 400 & 246 & 536 & 3460 & 232 & 383 & 3792 \\
\hline & 500 & 305 & 634 & 4325 & 276 & 402 & 4740 \\
\hline & 600 & 329 & 549 & 5190 & 308 & 380 & 5688 \\
\hline & 700 & 352 & 491 & 6055 & 344 & 384 & 6636 \\
\hline & 800 & 404 & 554 & 6920 & 382 & 397 & 7584 \\
\hline & 900 & 428 & 518 & 7785 & 420 & 411 & 8533 \\
\hline & 1000 & 476 & 568 & 8650 & 451 & 408 & 9481 \\
\hline \multirow[t]{10}{*}{$10 \%(\mathrm{v} / \mathrm{v}) \mathrm{DHP}$} & 100 & 125 & 1328 & 836 & 120 & 987 & 916 \\
\hline & 200 & 215 & 1549 & 1671 & 209 & 1193 & 1832 \\
\hline & 300 & 291 & 1628 & 2507 & 287 & 1303 & 2748 \\
\hline & 400 & 362 & 1709 & 3343 & 349 & 1287 & 3664 \\
\hline & 500 & 423 & 1709 & 4179 & 415 & 1351 & 4580 \\
\hline & 600 & 492 & 1818 & 5014 & 479 & 1407 & 5496 \\
\hline & 700 & 550 & 1836 & 5850 & 544 & 1489 & 6412 \\
\hline & 800 & 608 & 1876 & 6686 & 596 & 1477 & 7328 \\
\hline & 900 & 664 & 1905 & 7522 & 651 & 1501 & 8244 \\
\hline & 1000 & 722 & 1960 & 8357 & 697 & 1483 & 9160 \\
\hline \multirow[t]{10}{*}{$20 \%(\mathrm{v} / \mathrm{v}) \mathrm{DHP}$} & 100 & 135 & 2124 & 730 & 135 & 1782 & 800 \\
\hline & 200 & 225 & 2297 & 1459 & 228 & 1974 & 1599 \\
\hline & 300 & 318 & 2731 & 2189 & 311 & 2139 & 2399 \\
\hline & 400 & 396 & 2861 & 2918 & 387 & 2243 & 3198 \\
\hline & 500 & 455 & 2736 & 3648 & 451 & 2231 & 3998 \\
\hline & 600 & 527 & 2889 & 4377 & 523 & 2361 & 4798 \\
\hline & 700 & 592 & 2952 & 5107 & 574 & 2266 & 5597 \\
\hline & 800 & 659 & 3068 & 5836 & 632 & 2278 & 6397 \\
\hline & 900 & 712 & 3022 & 6566 & 658 & 2021 & 7196 \\
\hline & 1000 & 776 & 3138 & 7296 & 734 & 2241 & 7996 \\
\hline \multirow[t]{10}{*}{$30 \%(\mathrm{v} / \mathrm{v})$ DHP } & 100 & 159 & 4577 & 624 & 147 & 3060 & 684 \\
\hline & 200 & 237 & 3607 & 1247 & 235 & 2933 & 1367 \\
\hline & 300 & 344 & 4642 & 1871 & 327 & 3353 & 2051 \\
\hline & 400 & 420 & 4593 & 2495 & 411 & 3608 & 2734 \\
\hline & 500 & 496 & 4728 & 3118 & 479 & 3578 & 3418 \\
\hline & 600 & 564 & 4755 & 3742 & 537 & 3450 & 4101 \\
\hline & 700 & 639 & 4983 & 4366 & 621 & 3832 & 4785 \\
\hline & 800 & 702 & 4984 & 4989 & 677 & 3759 & 5468 \\
\hline & 900 & 775 & 5232 & 5613 & 742 & 3867 & 6152 \\
\hline & 1000 & 840 & 5332 & 6237 & 807 & 3973 & 6836 \\
\hline \multirow[t]{10}{*}{$40 \%(\mathrm{v} / \mathrm{v}) \mathrm{DHP}$} & 100 & 147 & 5346 & 516 & 148 & 4515 & 565 \\
\hline & 200 & 251 & 6177 & 1032 & 245 & 4796 & 1131 \\
\hline & 300 & 357 & 7466 & 1548 & 344 & 5615 & 1696 \\
\hline & 400 & 442 & 7710 & 2063 & 434 & 6133 & 2262 \\
\hline & 500 & 530 & 8280 & 2579 & 506 & 6081 & 2827 \\
\hline & 600 & 609 & 8565 & 3095 & 588 & 6466 & 3392 \\
\hline & 700 & 688 & 8892 & 3611 & 656 & 6497 & 3958 \\
\hline & 800 & 727 & 8007 & 4127 & 703 & 6074 & 4523 \\
\hline & 900 & 782 & 7783 & 4643 & 768 & 6170 & 5088 \\
\hline & 1000 & 857 & 8172 & 5159 & 825 & 6133 & 5654 \\
\hline \multirow[t]{13}{*}{$50 \%(\mathrm{v} / \mathrm{v}) \mathrm{DHP}$} & 100 & 150 & 8465 & 420 & 144 & 6364 & 460 \\
\hline & 200 & 252 & 9295 & 840 & 249 & 7568 & 920 \\
\hline & 300 & 341 & 9858 & 1259 & 345 & 8486 & 1380 \\
\hline & 400 & 444 & 11723 & 1679 & 442 & 9645 & 1840 \\
\hline & 500 & 565 & 14860 & 2099 & 555 & 11831 & 2300 \\
\hline & 600 & 633 & 14304 & 2519 & 597 & 10133 & 2761 \\
\hline & 700 & 706 & 14348 & 2939 & 652 & 9580 & 3221 \\
\hline & 800 & 767 & 13931 & 3358 & 693 & 8756 & 3681 \\
\hline & 900 & 837 & 14139 & 3778 & 769 & 9293 & 4141 \\
\hline & 1000 & 938 & 15800 & 4198 & 801 & 8486 & 4601 \\
\hline & 800 & 832 & 27562 & 2666 & 800 & 20655 & 2922 \\
\hline & 900 & 856 & 23683 & 2999 & 845 & 19060 & 3287 \\
\hline & 1000 & 927 & 24087 & 3333 & 922 & 19793 & 3653 \\
\hline
\end{tabular}


Table S8b. Dimensionless groups used in dimensional analysis for all solutions at 308 and $313 \mathrm{~K}$

\begin{tabular}{|c|c|c|c|c|c|c|c|}
\hline \multirow[t]{2}{*}{$\%(\mathrm{v} / \mathrm{v}) \mathrm{DHP}$} & \multirow[t]{2}{*}{$\mathrm{rpm}$} & \multicolumn{2}{|l|}{$308 \mathrm{~K}$} & & \multicolumn{3}{|l|}{$313 \mathrm{~K}$} \\
\hline & & $S h=k l / D$ & $S c=v / D$ & $R e=l U N$ & $S h=k l / D$ & $S c=\mathrm{v} / D$ & $0 \%(\mathrm{v} / \mathrm{v}) \mathrm{DHP}$ \\
\hline \multirow[t]{7}{*}{100} & 181 & 22797 & 333 & 190 & 21614 & 365 & \\
\hline & 200 & 328 & 30803 & 667 & 339 & 28244 & 731 \\
\hline & 300 & 409 & 25872 & 1000 & 420 & 23213 & 1096 \\
\hline & 400 & 523 & 29266 & 1333 & 522 & 24242 & 1461 \\
\hline & 500 & 630 & 31754 & 1666 & 584 & 21484 & 1826 \\
\hline & 600 & 701 & 30046 & 2000 & 618 & 17609 & 2192 \\
\hline & 700 & 734 & 25221 & 2333 & 711 & 19250 & 2557 \\
\hline
\end{tabular}

Table S9. Dimensionless correlation constants a and b under all studies conditions

\begin{tabular}{lcccc}
\hline & $298 \mathrm{~K}$ & $303 \mathrm{~K}$ & $308 \mathrm{~K}$ & $313 \mathrm{~K}$ \\
\hline Constant $a$ & & & & \\
Blank, 0\% (v/v) DHP & 0.1010 & 0.0993 & 0.0996 & 0.0982 \\
10\% (v/v) DHP & 0.1031 & 0.1026 & 0.1025 & 0.1014 \\
$20 \%$ (v/v) DHP & 0.1036 & 0.1042 & 0.1036 & 0.1046 \\
$30 \%$ (v/v) DHP & 0.1058 & 0.1063 & 0.1065 & 0.1052 \\
$40 \%$ (v/v) DHP & 0.1084 & 0.1055 & 0.1060 & 0.1060 \\
$50 \%$ (v/v) DHP & 0.1058 & 0.1064 & 0.1055 & 0.1074 \\
$60 \%$ (v/v) DHP & 0.1063 & 0.1124 & 0.1138 & 0.1157 \\
Constant $b$ & & & & \\
Blank, 0\% (v/v) DHP & 0.7044 & 0.7051 & 0.7038 & 0.7044 \\
$10 \%$ (v/v) DHP & 0.7052 & 0.7046 & 0.7041 & 0.7046 \\
$20 \%$ (v/v) DHP & 0.7059 & 0.7044 & 0.7044 & 0.7023 \\
$30 \%$ (v/v) DHP & 0.7054 & 0.7037 & 0.7027 & 0.7033 \\
$40 \%$ (v/v) DHP & 0.7040 & 0.7066 & 0.7049 & 0.7040 \\
$50 \%$ (v/v) DHP & 0.7096 & 0.7078 & 0.7074 & 0.7039 \\
$60 \%$ (v/v) DHP & 0.7096 & 0.7029 & 0.7000 & 0.6970 \\
\hline
\end{tabular}

Table S10. Values of the limiting current density $\left(I_{1}\right)$, angular velocity $(\omega)$, kinematic viscosity $(v)$, diffusion coefficient (D), and dimensionless groups used in dimensional analysis for blank and 20\% (v/v) DHP at high speeds of rotation and 298K

\begin{tabular}{|c|c|c|c|c|c|c|c|c|}
\hline & $\mathrm{I}_{1}\left(\mathrm{~mA} \mathrm{~cm} \mathrm{~cm}^{-2}\right)$ & $\mathrm{rpm}$ & $\omega$ & $v$ (stoke) & $\mathrm{D}\left(\mathrm{cm}^{2} \mathrm{~s}^{-1} \times 10^{5}\right)$ & $\mathrm{Sh}=\mathrm{kl} / \mathrm{D}$ & $\mathrm{Sc}=\mathrm{v} / \mathrm{D}$ & $\mathrm{Re}=1 \mathrm{U} / \mathrm{v}$ \\
\hline \multirow[t]{10}{*}{ Blank, 0\% (v/v) DHP } & 67.57 & 1500 & 157.1 & 0.0098616 & 0.458 & 912 & 2086 & 11294 \\
\hline & 83.32 & 2000 & 209.4 & & 0.464 & 1110 & 2060 & 15059 \\
\hline & 96.50 & 2500 & 261.8 & & 0.457 & 1305 & 2090 & 18823 \\
\hline & 103.55 & 3000 & 314.2 & & 0.419 & 1530 & 2284 & 22588 \\
\hline & 118.50 & 3500 & 366.5 & & 0.436 & 1679 & 2191 & 26352 \\
\hline & 125.85 & 4000 & 418.9 & & 0.415 & 1877 & 2307 & 30117 \\
\hline & 129.87 & 4500 & 471.2 & & 0.383 & 2097 & 2497 & 33882 \\
\hline & 147.25 & 5000 & 523.6 & & 0.415 & 2194 & 2304 & 37646 \\
\hline & 148.46 & 5500 & 576.0 & & 0.379 & 2422 & 2523 & 41411 \\
\hline & 151.03 & 6000 & 628.3 & & 0.354 & 2638 & 2700 & 45176 \\
\hline \multirow[t]{12}{*}{$20 \%(\mathrm{v} / \mathrm{v})$ DHP } & 38.62 & 1500 & 157.1 & 0.012545 & 0.186 & 1242 & 4973 & 11294 \\
\hline & 46.51 & 2000 & 209.4 & & 0.181 & 1532 & 5094 & 15059 \\
\hline & 54.30 & 2500 & 261.8 & & 0.181 & 1793 & 5105 & 18823 \\
\hline & 62.02 & 3000 & 314.2 & & 0.182 & 2031 & 5062 & 22588 \\
\hline & 69.81 & 3500 & 366.5 & & 0.185 & 2249 & 4981 & 26352 \\
\hline & 76.33 & 4000 & 418.9 & & 0.184 & 2475 & 5014 & 30117 \\
\hline & 78.91 & 4500 & 471.2 & & 0.171 & 2762 & 5412 & 33882 \\
\hline & 87.20 & 5000 & 523.6 & & 0.178 & 2931 & 5197 & 37646 \\
\hline & 102.85 & 5500 & 576.0 & & 0.207 & 2967 & 4461 & 41411 \\
\hline & 100.31 & 6000 & 628.3 & & 0.181 & 3307 & 5098 & 45176 \\
\hline & 104.62 & 6500 & 680.7 & & 0.177 & 3525 & 5209 & 48940 \\
\hline & 97.60 & 7000 & 733.0 & & 0.147 & 3970 & 6289 & 52705 \\
\hline
\end{tabular}

